United States

Lepartment of

iculture

Forest

Service

Conservation

Research

Report

No. 27

(iis)

\title{
Rare and Endemic Trees of Puerto Rico and the Virgin Islands
}

CUlifil re...nth RECORDS

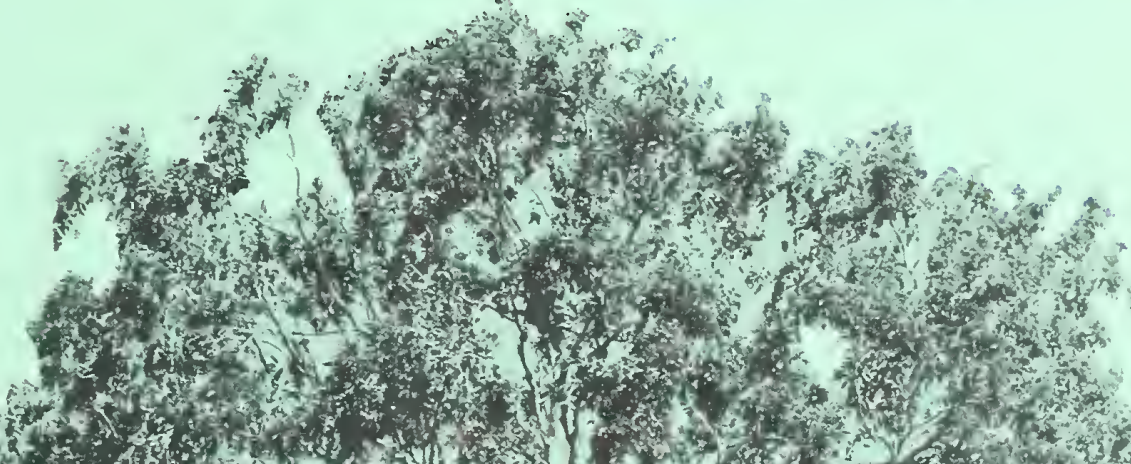

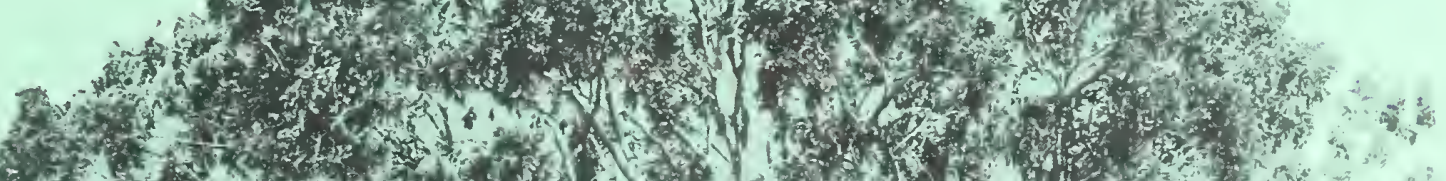

解

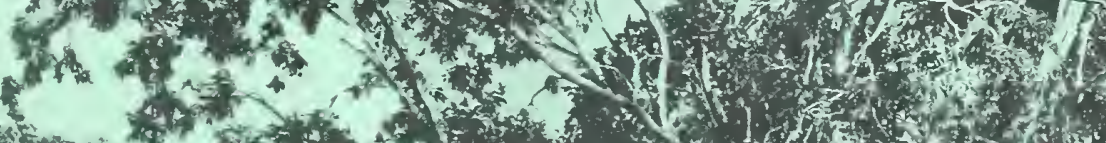

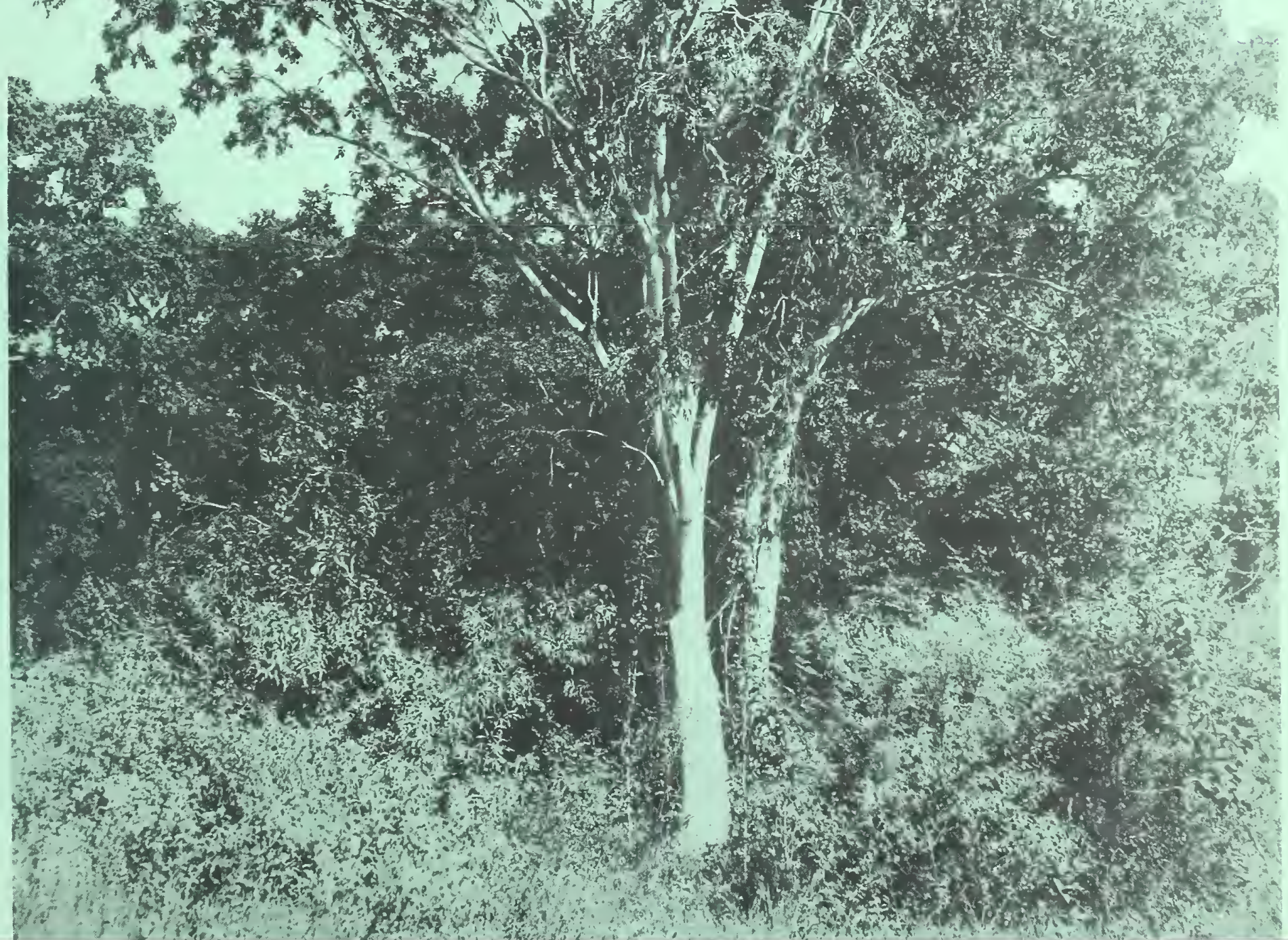




\section{Historic, archived document}

Do not assume content reflects current scientific knowledge, policies, or practices. 



\section{Rare and Endemic Trees of Puerto Rico and the Virgin Islands}

by

Elbert L.' Little, Jr.

Chief Dendrologist (Retired)

Timber Management Research

U.S. Department of Agriculture

Forest Service

and

Roy O. Woodbury

Plant Taxonomist

University of Puerto Rico

United States Department of Agriculture

Forest Service

Conservation Research

Report No. 27

Washington, D.C.

November 1980

For sale by the Superintendent of Documents, U.S. Government Printing Office Washington, D.C. 20402 


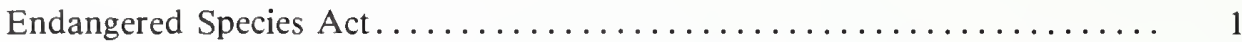

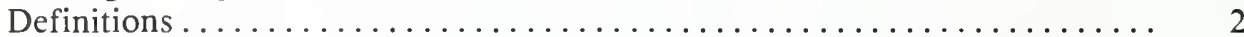

Previous Work................................ 3

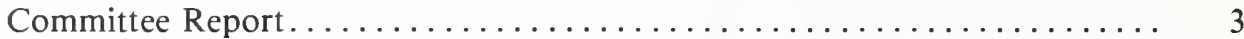

Lists of Trees of Puerto Rico and the Virgin Islands.............. 4

1. Extinct Species............................. 4

2. Rare Endemic Species Needing Additional Protection............ 5

3. Rare Endemic Species To Be Watched. . . . . . . . . . . . . . . . . . . 6

4. Other Rare Endemic Species....................... 7

5. Common Endemic Species...................... 8

6. Rare Species Native Beyond (Nonendemic). . . . . . . . . . . . . . 10

Endemic Species of Virgin Islands. . . . . . . . . . . . . . . . . . 13

Relationships of the Endemic Species.................... 15

Species New to Science............................ 15

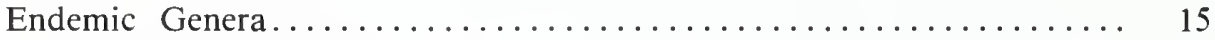

Trees Absent From Puerto Rico....................... 16

Public Forests and Parks............................ 18

Economic Importance of Endemic Species . . . . . . . . . . . . . . . . 19

Puerto Rico and Hawaii Compared...................... 20

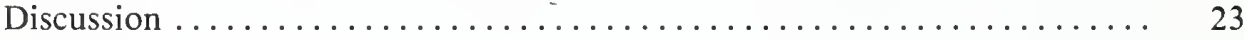

Summary .................................. 24

Literature Cited.................................. 25

Index of Scientific Names............................ 26

\section{Abstract}

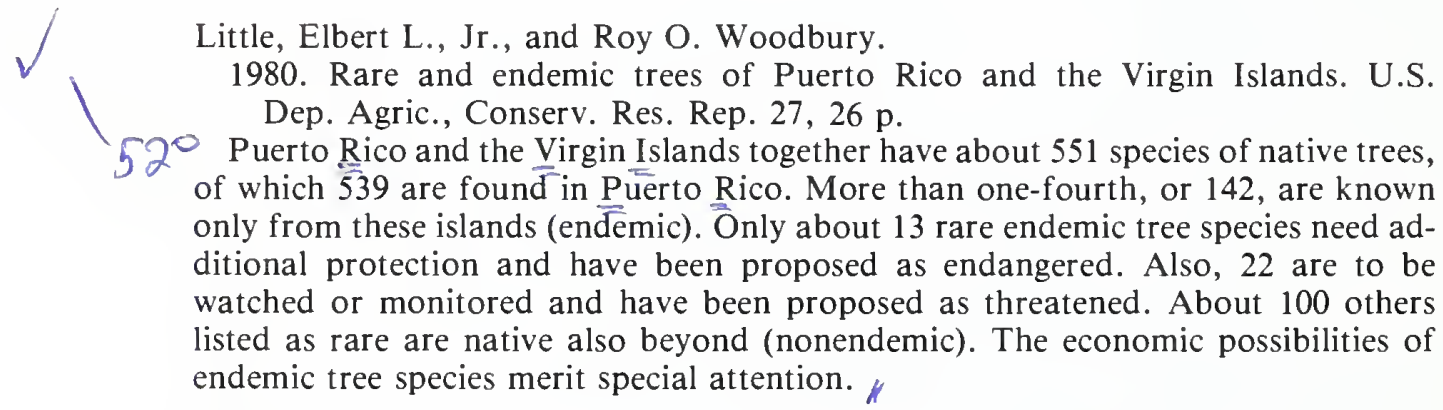

OXFORD: $174(729.5) ; 181.1 ; 907.2$.

KEY WORDS: Trees (Puerto Rico); trees (Virgin Islands); rare trees; rare and endangered plants; tree sanctuaries.

Cover: Violeta, violet-tree, Polygala cowellii (Britton) Blake, at Juana Díaz. Small to medium-sized tree scattered in forests of hillsides and arroyos. Native only in Puerto Rico and classed as a rare endemic species to be watched. Beautiful masses of violet-colored flowers cover the tree from February to March or April, generally when leafless. Photograph by Frank H. Wadsworth. 


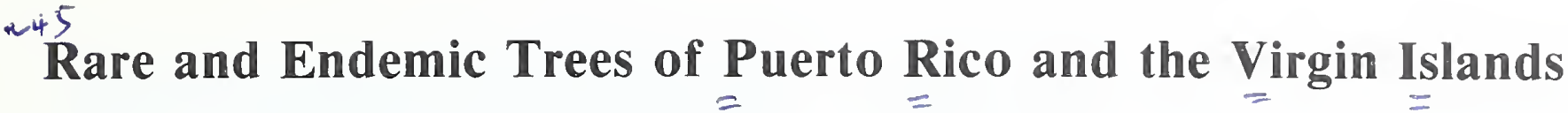

\author{
By Elbert L. Little, Jr., and Roy O. Woodbury ${ }^{1}$
}

\section{Introduction}

Like other oceanic islands, Puerto Rico and the Virgin Islands are rich in rare and local plant species not found elsewhere. Fortunately, most native tree species are protected in natural or near natural forests within public forests and parks. Very few tree species, mostly confined to privately owned lands, need additional protection.

This report groups the species of rare and endemic trees into lists; summarizes present occurrence, and may be of use for planning, development, management, and preservation of land. It is one of a series on rare trees of the United States. ${ }^{2}$ The British Virgin Islands, which have very few additional species, have been included, as in previous studies. The information summarized here is based largely upon field studies by the authors in Puerto Rico and the Virgin Islands through many years.

Nearly all the rare and local trees of this report are present within Puerto Rico. Few of the same or other rare species are native in the smaller islands nearby, such as

\section{Endangered Species Act}

The Endangered Species Act of 1973 (public law 93-205) has directed attention to rare animal and plant species that may be classed as endangered and in need of protection against extinction. It provided legal definitions of two groups not previously separated, endangered and threatened species.

As authorized by this act, lists of proposed endangered and threatened plant species have been prepared by the Smithsonian Institution. The preliminary published lists $(21,24,25)$ contain more than 2,000 species and varieties in continental United States and many others in Hawaii.

\footnotetext{
${ }^{1}$ Respectively, chief dendrologist (retired), Timber Management Research, U.S. Department of Agriculture, Forest Service, Box 2417, Washington, D.C. 20013; and plant taxonomist, University of Puerto Rico, Rio Piedras, Puerto Rico 00928.

${ }^{2}$ Three others have been published $(8,9,10)$. Italic numbers in parentheses refer to Literature Cited, p. 25.
}

Mona, Culebra, and Vieques (all belonging to Puerto Rico), the U.S. Virgin Islands, and the British Virgin Islands.

The geological history helps to explain present tree distribution. Puerto Rico and adjacent islands began as submarine volcanoes on the ocean floor some 125 million years ago and were built up by the end of the early Cretaceous period about 80 million years ago. The time is sufficient for much accidental migration from the continents. There is some evidence that much higher peaks may have existed, that blocks have been uplifted and subsided, and that sea level may have fluctuated. During glacial periods the climate may have been cooler, vegetation zones as much as 3,000 ft (914 m) lower, and sea level $200 \mathrm{ft}(61 \mathrm{~m})$ lower. The Virgin Islands, except St. Croix, apparently were connected with one another and with Puerto Rico as recently as the maximum advance of the last continental glaciation about 11,000 years ago.

Separate lists of proposed endangered, threatened, and extinct species of Puerto Rico and the Virgin Islands have been included in a revision ( $I$ ).

The act also provides that the Secretary of the U.S. Department of the Interior must study the Smithsonian Institution's preliminary list and determine which species are truly threatened and endangered. The first official list, with additions through 1978, contains 17 plant species (only 1 a tree), with none from Puerto Rico and the Virgin Islands (26). 


\section{Definitions}

Trees may be defined as woody plants having one erect perennial stem or trunk at least 3 in $(7.5 \mathrm{~cm})$ in diameter at breast height (d.b.h. or at $4.5 \mathrm{ft}$ or $1.3 \mathrm{~m}$ ), a more or less definitely formed crown of foliage, and a height of at least $13 \mathrm{ft}(4 \mathrm{~m})(15, \mathrm{p} .14)$. Some small trees that are often shrubby and shrubby species rarely reaching the minimum tree size have been included.

Tree species are less numerous than those of smaller plants on lists of proposed endangered plants. Of course, tree species make up only a fraction of the seed plant species listed in a local flora, as high as one-fourth in the tropics and as low as one-tenth or less in temperate regions. Trees are conspicuous and easily located, watched, and mapped. Their large size and long life afford some protection against grazing animals and various hazards. They reproduce by seeds and from roots over a period of years. If endangered, they can be propagated readily by seeds or vegetative shoots and distributed to botanical gardens, parks, and arboreta.

A rare species is one that has a small population in its range, which may be restricted or widespread. The term local species is used here for one of relatively small range, but which is sufficiently common not to be called rare. A species whose range is limited to a particular named area, usually small, is cited as endemic.

Border or peripheral species reach the limit of their natural range a short distance into the United States, where they may also be classed as rare or local. They may be rare at the edges of their ranges but not in danger of extinction because of occurrence in greater numbers elsewhere. A species could become extinct in the United States and still be common in a neighboring country.
Some rare and local tree species are also on the lists of proposed endangered and threatened species compiled by the Smithsonian Institution (21). However, border or peripheral species generally are excluded by definition.

Two administrative or legal definitions may be quoted from the Endangered Species Act. "The term 'endangered species' means any species which is in danger of extinction throughout all or a significant portion of its range. . . ." The report by the Smithsonian Institution $(21$, p. 17$)$ adds: "Existence may be endangered because of the destruction, drastic modification, or severe curtailment of habitat, or because of overexploitation, disease, predation, or even unknown reasons. Plant taxa from very limited areas, e. g., the type localities only, or from restricted fragile habitats usually are considered endangered. Survival of an endangered species requires assistance and additional protection."

"The term 'threatened species' means any species which is likely to become an endangered species within the foreseeable future throughout all or a significant portion of its range." Included are species categorized as rare, very rare, or depleted. These species are to be watched.

Recently extinct or possibly extinct species are "those species of plants no longer known to exist after repeated search of the type localities and other known or likely places. Some species may be extinct in the wild but preserved by cultivation in gardens...." (21). (Of course, the reference is to the modern or recent flora named from collections of living plants and not to the wholly extinct fossil floras.) Species that have disappeared from one island, but not others, are not extinct. 


\section{Previous Work}

Detailed information on the native and introduced trees of Puerto Rico and the Virgin Islands (both United States and British) is contained in the 2-volume illustrated reference by the authors with Frank $\mathrm{H}$. Wadsworth (12, $13,15)$ and in publications cited there. The text compiled for each species includes common and scientific names, description (for nearly all), uses, and distribution within these islands and beyond. Presence within public forests and parks is mentioned.

That reference contains additional information on the rare and local trees not repeated here. The original drawings of 133 endemic tree species are the first ever published for most. This report adopts the same names and for convenience the same species numbers, $1-250$ in the first volume and 251-750 in the second.

The chapter in the second volume (15, p. 15-19) entitled "Endemic, Rare and Endangered Three Species" serves as a background for this promised, expanded report containing some more recent data. Lists in that volume $(15, \mathrm{p}$. iv-xiv and p. 19) designated the endemic species $(\mathrm{E})$ and those further grouped together as "rare or endangered"' (R).

\section{Committee Report}

"Rare and Endangered Plants of Puerto Rico" is a committee report published by the U.S. Department of Agriculture, Soil Conservation Service (23), in cooperation with the Department of Natural Resources, Commonwealth of Puerto Rico. Woodbury and two foresters from the Institute of Tropical Forestry served on this committee.

The committee report compiled in tabular form the rare and endangered plant species of Puerto Rico (omitting the Virgin Islands) totaling 409, including about 189 trees. The four parts, with number of tree species in each, were: Endangered Endemic Plants ( 74 tree species), Rare Endemic Plants (12), Endangered Nonendemic Plants (66), and Rare Nonendemic Plants (37). However, more than half the species listed were not endemic, and threatened species were not distinguished.

Lists of rare and endangered plant species were prepared for 10 public forests and 7 other localities where these species were concentrated. The 7 localities of privately owned lands, mostly small, were: Coamo area (Coamo and east), Playa de Guayanés (Punta Guayanés), Campanillas area (Toa Baja), Lake Tortuguero area, Biafara area (near Arecibo), Monte la Torrecilla, and the Quebradillas area.
Endemic tree species of the Luquillo Mountains were listed in a study of the relationships (7). A later study of the trees of the Caribbean National Forest of 28,000 acres $(11,300 \mathrm{ha})$ within the Luquillo Mountains listed 225 species of native trees, more than in any equal area of continental United States (14). Among these species, 88 were classed as endemic or rare, 68 of these limited or endemic to Puerto Rico, and 23 of the 68 found wild only within the forest boundaries or slightly beyond. Weaver (28) cited 28 species including 18 trees as endemic to the Luquillo Mountains and found in the dwarf forest.

Local lists of trees or seed plants of smaller islands have been prepared by the authors $(5,6,16,31,32)$ and by others.

"Flora Portoricensis" by Urban (27) and "Botany of Porto Rico and the Virgin Islands" by Britton and Wilson (2) contained plant lists and descriptions and information on ranges and serve as a foundation for later studies. Analyses of geographic distribution of the flora were made by Urban (27, p. 675-689) and by Gleason and Cook (3). Studies of the fossil flora, for example, that of an Oligocene formation by Graham and Jarzen (4), have stressed the importance of time in relation to the present geographic occurrence in space.

Recommendations for a plan of action included: (I) Reduction of causes of endangerment by: (A) Habitat preservation and management including creation of new sanctuary areas, (B) regulation of plant collecting for ornamental and other uses, $(C)$ curtailment of lumbering and consideration of a plan to replant, and (D) reseeding; (II) information and education; and (III) monitoring and research.

New sanctuary areas were suggested for: (1) Forests of the Central Mountains and limestone hills; (2) Lake Tortuguero and adjacent swamplands; (3) dry forest habitat in the southwest; (4) off-shore islands such as Mona, Culebra, and Vieques; and (5) other specific areas with unique plants, as mapped.

The recommendation for reseeding included outplanting, propagation of very rare species in botanical gardens within these islands, and distribution of seeds to parks and gardens in other parts of the world. Monitoring involved surveying and mapping the range of each endangered species and watching other rare species for possible decrease in numbers or habitat destruction. 


\section{Lists of Trees of Puerto Rico and the Virgin Islands}

Puerto Rico and the Virgin Islands have about 551 species of native trees. The 2 -volume reference $(12,13$, 15) accepted 547. Five additions of shrub species observed by Woodbury to reach tree size are mentioned below and numbered to indicate place of insertion in the second volume. They were listed as rare and endangered trees in the committee report. Two are additional endemic tree species. Also, Malpighia shaferi Britton \& Wils., an endemic, has been united recently as a synonym of $421, M$. fucata Ker, palobronco.

368.1. Caesalpinia monensis Britton, mato negro, Leguminosae, legume family. Rare shrub or small tree to $20 \mathrm{ft}(6.1 \mathrm{~m})$ high and 5 in $(13 \mathrm{~cm})$ in trunk diameter. The only endemic tree species of Mona Island.

446.1. Phyllanthus cuneifolius (Britton) Croizat (Andrachne cuneifolia Britton), Euphorbiaceae, spurge family. Shrub or small tree to 15-20 ft (4.6-6.1 m) high and 3 in $(7.5 \mathrm{~cm})$ in trunk diameter, rare and very local on southern coast. Also Hispaniola and Cuba.

495.1 Hibiscus clypeatus L., Malvaceae, mallow family. Very rare tree to $20 \mathrm{ft}(6.1 \mathrm{~m})$ high and 4 in $(10 \mathrm{~cm})$ in trunk diameter, near Guánica. Public forest-Guánica. Greater Antilles, Cayman Islands, and Mexico. Reported long ago from St. Croix.

538.1. Leptocereus quadricostatus (Bello) Britton \& Rose (Cereus quadricostatus Bello), sebucán, Cactaceae, cactus family. Rare cactus sometimes forming a trunk to $1 \mathrm{ft}(30 \mathrm{~cm})$ in diameter, mostly shrubby and vinelike. Endemic to southwestern Puerto Rico and Icacos. Public forest-Guánica.

676.1. Rochefortia cuneata Sw., espino, Boraginaceae, borage family. Shrub or small tree to $25 \mathrm{ft}$ ( 7.6 $\mathrm{m})$ high and 5 in $(13 \mathrm{~cm})$ in trunk diameter, near Quebradillas. Very rare, cited by Britton and Wilson (2) earlier from La Plata near Guánica and from Sardinera near Dorado. Recorded also from Jamaica, Hispaniola, Antigua, Guadeloupe, Dominica, and Martinique.

About 539 of the 551 tree species are found in Puerto Rico. Thus, the Virgin lslands have about 12 additional tree species that are not present on the larger island.

This total is much greater than that of any of the 50 States. The State of Hawaii, for example, has about 370 named trees on 8 islands, though the number could be reduced perhaps to fewer than 300 through union of minor variations. Florida has about 272 species of native trees including nearly 100 tropical species in the southern part not native elsewhere in continental United States (11).

More than one-fourth, or 142 of the 551 species, of native trees in Puerto Rico and the Virgin Islands are known only from these islands (endemic), including about 83 classed as rare. About 100 others listed as rare are native also beyond (nonendemic). Thus, endemic and rare species together as listed in this report total about 242 , more than two-fifths.
These rare and endemic trees can be grouped here into six lists, as follows: (1) Extinct species, (2) endemic species needing protection, (3) endemic species to be watched, (4) other rare endemic species, (5) common endemic species, and (6) rare nonendemic species. As used here, rare species are those in lists (1), (2), (3), (4), and (6) combined. In the following six lists, the plant families and species are arranged alphabetically for comparison with similar lists.

\section{Extinct Species}

No endemic tree species of Puerto Rico and the Virgin Islands is known to have become extinct. However, a few border or peripheral species may have disappeared there.

These islands were discovered in 1493 by Christopher Columbus on his second voyage and were among the first to be occupied by colonists from Europe. For many years, Puerto Rico has had a high population density, both rural and urban. As a result, undisturbed vegetation is very restricted in area, and habitat destruction has been widespread.

The native vegetation developed in the absence of large mammals, such as herbivores, and may have been susceptible to introduced goats and cattle. However, trees would be less affected than smaller plants. Dry forests, which can be damaged severely by grazing animals, are restricted in Puerto Rico, though common in nearby islands including the Virgin Islands. The lowland coastal areas, where the first settlements were made, have few endemics. The mountain forests, centers of endemism, remained nearly undisturbed for centuries.

There is no indication that any rare plants, and trees in particular, may have been eliminated by human activities before the arrival of plant collectors. As early as 1793 , a 363-page flora of St. Croix and others of the Virgin Islands was published by West (29), head of the school in St. Croix. However, three centuries had lapsed since the discovery by Columbus.

Almost all the endemic tree species named long ago from Puerto Rico or the Virgin Islands have been found by later collectors including the present authors. Likewise, nearly all rare border or peripheral species of older lists have been located. Several tree species not observed by Nathaniel L. Britton and associates during the preparation of the flora have been rediscovered in recent years. Besides, a few range extensions from other islands and undescribed species have been detected. Botanical exploration of remote areas increased with accessibility after construction of a network of highways. For many years, every part of Puerto Rico has been within 5 miles of a paved road.

Four species of the large myrtle family, Myrtaceae, were published long ago from incomplete specimens and 
were never again collected. They should not have been named. These poorly known, inadequately described species listed below probably should be excluded, rather than classed as extinct.

552. Calyptranthes kiaerskovii Krug \& Urban. The only endemic tree of Tortola, named in 1895 from a sterile specimen. Possibly an accidental migrant of a widespread species.

563. Eugenia boqueronensis Britton. Named in 1924 from a specimen without fruit collected by its author and others at Salinas de Boquerón in 1915.

567. Eugenia (?) corozalensis Britton. Published in 1924 for a sterile specimen collected the year before at Corozal.

576. Eugenia serrasuela Krug \& Urban, serrazuela. Reported from Anones by Bello before 1881 and named in 1895 .

The 2 rare nonendemic tree species listed below may be extinct locally.

300. Urera caracasana (Jacq.) Gaud., ortiga colorada, stinging nettle, Urticaceae, nettle family. This widespread tropical American species was collected long ago in Luquillo Mountains, where it may possibly be extinct. Apparently it is the ancestor of the Puerto Rican endemic, Urera chlorocarpa Urban. Thus, instead of disappearing, the plants evolved into a different species.

447. Ottoschulzia rhodoxylon (Urban) Urban, Icacinaceae, icacina family. A very rare tree named in 1908 from a specimen without flowers or fruit collected near Mayaguez in 1876. Not seen in Puerto Rico in recent years but located in Hispaniola as a range extension.

The next 3 examples illustrate rediscovery of lost tree species.

449. Sapium caribaeum Urban, Euphorbiaceae, spurge family. Collected at Cinnamon Bay, St. John, about a century ago but not found there afterwards. Sterile specimens were obtained on Sage Mountain, Tortola (British Virgin Islands), in 1954 and 1972 by Little. Also Lesser Antilles to St. Vincent.

285. Juglans jamaicensis C. DC., nogal, West Indian walnut, Juglandaceae, walnut family. Collected in Puerto Rico recently by Woodbury for the first time since 1915. Native also in Cuba and Hispaniola but not Jamaica.

268. Pseudophoenix sargentii $\mathrm{H}$. Wendl., Florida cherrypalm, Palmae, palm family. One small tree was found on Mona Island west of Puerto Rico in 1970 by Woodbury, who located 3 others there later. All have since been cut. The range including varieties extends from Hispaniola to Cuba, Bahamas, Upper Florida Keys, Mexico, Belize, and Dominica. Additional trees were found on Mona in 1979.

\section{Rare Endemic Species Needing Additional Protection}

Several endemic tree species apparently need additional protection because they are very rare and limited in area and because they grow mostly on privately owned lands subject to other uses and destruction of the habitat. The 13 species listed below have been proposed also as endangered (I). Five are recorded from public forests, while 3 are absent from Puerto Rico. The 4 poorly known, inadequately described species of Myrtaceae mentioned above could be added here, if ever found again.

459. Ilex cookii Britton \& Wils., Aquifoliaceae, holly family. Rare shrub or small tree local in dwarf forest at and near summit of Cerro de Punta, in the central mountains at 4,000-4,390 $\mathrm{ft}(1,219-1338 \mathrm{~m})$ altitude. Toro Negro Forest.

702. Crescentia portoricensis Britton, Bignoniaceae, bignonia family. Vinelike shrub or sometimes small tree rare in lower Cordillera forest at $800-2,500 \mathrm{ft}$ (244-762 m) altitude in foothills of southwestern Puerto Rico. Maricao and Susúa Forests.

454. Buxus vahlii Baill., Buxaceae, box family. Rare shrub or small tree in moist limestone forest at $200-500 \mathrm{ft}$ (61-152 m) altitude on hills of Puerto Rico. One colony is being destroyed. Collected near Rincón, Ponce, and Bayamón. Also St. Croix.

524. Banara vanderbiltii Urban, Flacourtiaceae, flacourtia family. A very rare shrub or small tree now known from only 2 small trees on a farm near Bayamón. The fruits have not been described. Moist limestone forest at about $300 \mathrm{ft}(91 \mathrm{~m})$ altitude in Puerto Rico. First found near Cataño in 1899 and near Martín Peña. Named in 1902.

425. Malpighia pallens Small, stingingbush, Malpighiaceae, malpighia family. A shrub or small tree confined to St. Croix and Buck Island, though reported also from Cuba. Public park-Buck Island Reef National Monument.

498. Sida eggersii E. G. Baker, Malvaceae, mallow family. Britton and Wilson $(2,5: 555)$ called this "one of the most interesting species of our Flora." This small or medium-sized tree was named in 1892 for the collector, who found it in Tortola (British Virgin Islands). Afterwards, this species was collected twice on Culebra by $\mathrm{N}$. L. Britton and W. M. Wheeler in 1906 and by J. A. Shafer in 1913. Apparently, it may be extinct on that small island east of Puerto Rico. One tree was discovered on Jost Van Dyke (British Virgin Islands) in 1967 by Little (6). In 1975, Woodbury and others found a large number of the trees on Tortola.

416. Trichilia triacantha Urban, Meliaceae, mahogany family. Rare shrub or small tree near Guánica and Peñuelas in dry limestone forest at 100-200 ft (30-61 m) altitude in southwestern Puerto Rico. Guánica Forest. 
557. Calyptranthes thomasiana Berg, Myrtaceae, myrtle family. Flowers and fruits have not been described. Shrub and small tree local on mountains at $300-800 \mathrm{ft}$ (91-244 $\mathrm{m}$ ) altitude in St. Thomas and Vieques. Named from St. Thomas in 1855 and found on Vieques by Woodbury.

304. Schoepfia arenaria Britton, Olacaceae, olax family. Rare shrub, sometimes small tree, in moist coastal and lower Cordillera forests at $100-1,500 \mathrm{ft}(30-457 \mathrm{~m})$ altitude in northern foothills of Puerto Rico. Discovered at San José Lagoon, Santurce, and afterwards found near Quebradillas. Of limited distribution on privately owned land and Río Abajo Forest.

265. Calyptronoma rivalis (O. F. Cook) L. H. Bailey, palma manaca, Puerto Rican manac, Palmae, palm family. The rarest of Puerto Rican palms, named in 1901, has been known from only about 20 plants of all sizes growing along a marshy stream about 3 miles $(4.8 \mathrm{~km})$ east of San Sebastián in northwestern Puerto Rico. The present owner has expressed an intent to protect the remaining trees. It is reported that a second grove nearby might have been destroyed by clearing. Young plants are growing in the botanical garden of the University of Puerto Rico at Lajas. Recently, Woodbury has discovered another grove in Tanama River Gorge near Quebradillas.

407. Zanthoxylum thomasianum (Krug \& Urban) Krug \& Urban, Rutaceae, rue family. Rare shrub or small tree in lower Cordillera forest at 500-1,500 ft (152-457 $\mathrm{m}$ ) altitude on south slopes of Coamo-Cayey area in Central Cordillera of Puerto Rico. Also mountain forests of St. Thomas and St. John (Virgin Islands National Park).

694. Goetzea elegans Wydler, matabuey, Solanaceae, nightshade family. Small tree, very rare and local, known only from a few places in the moist limestone and moist coastal forests at $200-600 \mathrm{ft}(61-183 \mathrm{~m})$ altitude on north coast of Puerto Rico. Collected near Aquadilla, Guajataca Gorge near Quebradillas, Guajataca Forest, Cambalache Forest, and in 1883 at Jiménez near Río Grande, north of Luquillo Mountains. Worthy of cultivation as an ornamental with showy orange flowers and orange fruit.

521. Daphnopsis hellerana Urban, Thymelaeaceae, mezereon family. Shrub or small tree rare on or near summits of limestone hills or mogotes at 80-500 ft (24$152 \mathrm{~m}$ ) altitude in moist limestone forest of northern Puerto Rico. Collected west of Bayamón, south of Dorado, and west to Guajataca Gorge near Quebradillas. Discovered near Bayamón in 1900, named the next year, and not collected again until rediscovered by Woodbury in 1958 (17).

\section{Rare Endemic Species To Be Watched}

Several rare endemic tree species should be watched or monitored because of their restricted occurrence, partly on private land. At present they do not need additional protection, because representative areas of their habitat are preserved, partly within public forests and parks. The 22 species listed below have been proposed as threatened (1).

\section{Cactaceae, Cactus Family}

538.1. Leptocereus quadricostatus (Bello) Britton \& Rose (Cereus quadricostatus Bello), sebucán. Rare cactus sometimes forming a trunk to $1 \mathrm{ft}(30 \mathrm{~cm})$ in diameter, mostly shrubby and vinelike. Endemic to southwestern Puerto Rico and Icacos. Public forest-Guánica.

\section{Canellaceae, Canella Family}

522. Pleodendron macranthum (Baill.) v. Tiegh., chupacallos. Small or medium-sized tree very rare in forests in lower Luquillo Mountains and moist limestone regions. Reported from Guajataca and near Arecibo. Public forests-Luquillo, Rio Abajo. This distinctive aromatic tree discovered in $1822-23$ is one of the very rarest in Puerto Rico. Foresters rediscovered it in 1938 and 1940 in a remote part of Luquillo Mountains and had the drawing made. It doubtless persists in that undisturbed, poorly accessible locality, though there has been no later search.

\section{Celastraceae, Bittersweet Family}

470. Maytenus cymosa Krug \& Urban. Rare small tree in coastal moist forests of lowlands below $100 \mathrm{ft}(30 \mathrm{~m})$ altitude in eastern Puerto Rico (for example, near Fajardo) and islands eastward. Also Piñeros, Vieques, St. Croix, St. Thomas, and Virgin Gorda. Within Gorda Peak National Park, Virgin Gorda (British Virgin Islands).

472. Maytenus elongata (Urban) Britton. Shrub or small tree rare in moist limestone and lower Cordillera forests at 500-2,500 $\mathrm{ft}(152-762 \mathrm{~m})$ altitude, also Luquillo Mountains (El Verde). Public forests-Guajataca, Luquillo, Maricao, Susúa.

473. Maytenus ponceana Britton. Rare tree in moist limestone and lower Cordillera forests at $500-2,000 \mathrm{ft}$ $(152-610 \mathrm{~m})$ altitude in foothills through Puerto Rico, for example, near Arecibo and Lares. Public forests-Guajataca, Maricao, Río Abajo.

\section{Leguminosae, Legume Family}

368.1. Caesalpinia monensis Britton, mato negro. Rare shrub or small tree to $20 \mathrm{ft}(6.1 \mathrm{~m})$ high and 5 in (13 $\mathrm{cm})$ in trunk diameter. The only endemic tree species of Mona Island.

79. Stahlia monosperma (Tul.) Urban, cóbana negra. Small or medium-sized tree rare in coastal forests of southwestern and southeastern Puerto Rico and in Vieques. Public forest-Boquerón. Afterwards found near Macao, eastern Dominican Republic, and thus technically not endemic. 


\section{Myrtaceae, Myrtle Family}

553. Calyptranthes luquillensis Alain. Shrub or small tree rare in upper Luquillo forest at $2,000 \mathrm{ft}(610 \mathrm{~m})$ altitude. Public forest-Luquillo. First collected in 1939 and named in 1963.

570. Eugenia haematocarpa Alain, uvillo. Small tree rare in lower slopes of Luquillo forest at 1,000-1,500 ft (305-457 m) altitude in Luquillo Mountains, collected at Barrio Maizanales, El Valle, Naguabo, and at El Verde, Río Grande. Public forest-Luquillo. First collected in 1939 and named in 1963.

589. Marlierea sintenisii Kiaersk., beruquillo. Shrub or small tree rare in dwarf forest at $2,500 \mathrm{ft}(762 \mathrm{~m})$ altitude in Luquillo Mountains. Public forest-Luquillo. First collected nearly a century ago and rediscovered in 1940.

586. Myrcia (?) paganii Krug \& Urban. Tree very rare in moist limestone forest at 600-800 (183-244 m) altitude in northwestern Puerto Rico. Public forest-Guajataca. Flowers and fruits unknown. First collected nearly a century ago and rediscovered in 1959 by Woodbury.

584. Psidium sintenisii (Kiaersk.) Alain, hoja menuda. Small tree rare in upper Luquillo and upper Cordillera forests at 2,500-3,000 ft (762-914 m) altitude in eastern and western mountains of Puerto Rico. Public forests-Carite, Luquillo, Maricao. Perhaps to be united with a widespread related species.

\section{Polygalaceae, Milkwort Family}

117. Polygala cowellii (Britton) Blake, violeta, violettree. Small to medium-sized tree in forests of hillsides and arroyos, mostly in the southern coastal region but scattered also through the moist limestone and lower Cordillera regions of Puerto Rico. Rare on the limestone hills of the northern coast near Toa Baja, Vega Baja, and Arecibo. Public forest-Guánica.

\section{Rutaceae, Rue Family}

401. Ravenia urbanii Engler, tortugo prieto. Small tree rare in upper Luquillo and upper Cordillera forest regions at 1,500-3,000 $\mathrm{ft}$. (457-914 $\mathrm{m}$ ) altitude in eastern Puerto Rico. Public forests-Carite, Luquillo.

\section{Solanaceae, Nightshade Family}

690. Brunfelsia portoricensis Krug \& Urban. Shrub, rarely small tree, rare and very local in lower Luquillo forest at 1,500-1,800 ft (457-549 m) altitude in Luquillo Mountains only. Public forest-Luquillo.

696. Solanum drymophilum O. E. Schulz, erubia. Very rare shrub or small tree known only from upper Luquillo and Cordillera forest of eastern and central mountains (Luquillo to Cayey and Adjuntas) in Puerto Rico at middle and high altitudes $(2,500 \mathrm{ft}, 762 \mathrm{~m})$. Public forests-Carite, Luquillo, Toro Negro.

\section{Styracaceae, Storax Family}

650. Styrax portoricensis Krug \& Urban, palo de jazmín. Medium-sized tree very rare in Luquillo Mountains, found at Sierra de Naguabo and Yabucoa and near El Verde, also along Espiritu Santo River in Carite Forest. Public forests-Carite, Luquillo.

\section{Theaceae, Tea Family}

160. Laplacea portoricensis (Krug \& Urban) Dyer, maricao verde. Medium-sized tree found only in the lower Luquillo forest region. Public forest-Luquillo.

513. Ternstroemia luquillensis Krug \& Urban, palo colorado. Medium-sized tree rare in upper Luquillo forest at about $3,000 \mathrm{ft}(914 \mathrm{~m})$ altitude. Public forest-Luquillo.

516. Ternstroemia subsessilis (Britton) Kobuski. Very rare shrub or small tree in upper Luquillo and upper Cordillera forests at 2,500-3,000 ft (762-914 m) altitude near summits of Luquillo Mountains and Monte del Estado. Public forests-Luquillo, Maricao.

\section{Vedbenaceae, Verbena Family}

679. Callicarpa ampla Schauer, capá rosa. Rare shrub or medium-sized tree in wet forests in mountains from Luquillo to near Cayey and Utuado. Public forest-Luquillo. Recorded long ago from St. Thomas.

682. Cornutia obovata Urban, nigua. Small tree rare and local in moist limestone and Cordillera forests at $1,000-3,000 \mathrm{ft}(305-914 \mathrm{~m})$ altitude in central mountains of Puerto Rico. Discovered in 1885 on Monte Torrecillo near Barranquitas and 2 trees found there afterwards by Woodbury. Rediscovered in 1938 at Río Abajo Forest and near San Sebastián. One tree was found in Guajataca Forest in 1940 and later years. Public forests-Guajataca, Río Abajo.

\section{Other Rare Endemic Species}

About 44 other endemic tree species of Puerto Rico and the Virgin Islands listed below, are classed also as rare. Fortunately, they are present in sufficient numbers that they would not be considered threatened or endangered. Nearly all are protected within one or more public forests and parks. Almost all are cited in the second volume (15, p. iv-xiv and p. 19) as rare or endangered (R). Six species not indicated as rare in that list are added here: $336,512,590,607,636$, and 649 .

Aquifoliaceae, Holly Family

466. Ilex urbaniana Loes., cuero de sapo

Araliaceae, Ginseng Family

625. Didymopanax gleasonii Britton \& Wils., yuquilla 
Ebenaceae, Ebony Family

649. Diospyros sintenisii (Krug \& Urban) Standl., guayabota níspero

Ericaceae, Health Family

627. Lyonia rubiginosa (Pers.) G. Don

Euphorbiaceae, Spurge Family

126. Hyeronima clusioides (Tul.) Muell.-Arg., cedro macho

Flacourtiaceae, Flacourtia Family

523. Banara portoricensis Krug \& Urban, palo de ramón

534. Xylosma pachyphyllum (Krug \& Urban) Urban

536. Xylosma schwaneckeanum (Krug \& Urban) Urban, palo de candela

Lauraceae, Laurel Family

336. Ocotea portoricensis Mez, laurel de paloma

Leguminosae, Legume Family

380. Erythrina eggersii Krukoff \& Moldenke, piñón espinoso, cockspur

Melastomataceae, Melastome Family

596. Henriettea membranifolia (Cogn.) Alain, camasey

600. Miconia foveolata Cogn., camasey

607. Miconia pycnoneura Urban, camasey

617. Ossea krugiana Cogn.

620. Tetrazygia stahlii Cogn., camasey

Myricaceae, Waxmyrtle Family

284. Myrica holdridgeana Lundell, palo de cera

Myrsinaceae, Myrsine Family

631. Ardisia glauciflora Urban, mameyuelo

632. Ardisia luquillensis (Britton) Alain, mameyuelo

633. Grammadenia sintenisii (Urban) Mez (Cybianthopsis sintenisii (Urban) Lundell)

Myrtaceae, Myrtle Family

555. Calyptranthes portoricensis Britton

563. Eugenia boqueronensis Britton

576. Eugenia serrasuela Krug \& Urban

579. Eugenia stewardsonii Britton

590. Psidium amplexicaule Pers., mountain guava

Oleaceae, Olive Family

662. Linociera holdridgii Camp \& Monachino, hueso prieto

Palmae, Palm Family

4. Acrocomia media O. F. Cook, corozo, pricklypalm
5. Aiphanes acanthophylla (Mart.) Burret, palma de coyor

8. Gaussia attenuata (O. F. Cook) Beccari

Polygonaceae, Buckwheat Family

312. Coccoloba rugosa Desf., ortegón

Rhamnaceae, Buckthorn Family

486. Reynosia guama Urban, guamá

487. Reynosia krugii Urban

Rubiaceae, Madder Family

716. Antirhea portoricensis (Britton \& Wils.) Standl.

717. Antirhea sintenisii Urban, quina

739. Phialanthus grandifolius Alain, aquilón prieto

Sabiaceae, Sabia Family

485. Meliosma obtusifolia (Bello) Krug \& Urban, arroyo

Sapotaceae, Sapodilla Family

636. Bumelia krugii Pierre, araña gato

640. Dipholis bellonis Urban, tabloncillo

644. Manilkara pleeana (Pierre) Cronq., zapote de costa

Solanaceae, Nightshade Family

688. Brunfelsia densifolia Krug \& Urban

689. Brunfelsia lactea Krug \& Urban, vega blanca

Symplocaceae, Sweetleaf Family

651. Symplocos lanata Krug \& Urban, níspero cimarrón

652. Symplocos micrantha Krug \& Urban, aceitunilla

Theaceae, Tea Family

512. Ternstroemia heptasepala Krug \& Urban

Urticaceae, Nettle Family

301. Urera chlorocarpa Urban, ortiga, stinging nettle

\section{Common Endemic Species}

About 61 other endemic tree species of Puerto Rico and the Virgin Islands are classed as common or not rare. They are indicated in the second volume (15, p. ix-xiv and p. 19) as endemic (E). These 6 species classed as rare in that list have been found in greater numbers and are added here: $10,354,568,577,581$, and 635 .

Aquifoliaceae, Holly Family

465. Ilex sintenisii (Urban) Britton

Araliaceae, Ginseng Family

624. Dendropanax laurifolius (E. March.) R. C. Schneid., gongolí 
Bignoniaceae, Bignonia Family

235. Tabebuia haemantha (Bert.) DC., roble cimarrón

237. Tabebuia rigida Urban, roble de sierra

709. Tabebuia schumanniana Urban, roble colorado

\section{Boraginaceae, Borage Family}

222. Cordia borinquensis Urban, muñeco

674. Cordia rickseckeri Millsp., San Barlolomé, manjack

\section{Compositae, Composite Family}

750. Eupatorium portoricense Urban, guerrero

Cyatheaceae, Tree-fern Family

256. Alsophila bryophila Tryon, helecho gigante de la sierra, tree-fern

255. Nephelea portoricensis (Spreng.) Tryon, helecho gigante espinoso

\section{Euphorbiaceae, Spurge Family}

120. Croton poecilanthus Urban, sabinón

135. Croton rigidus (Muell. Arg.) Britton, adormidera

129. Sapium laurocerasus Desf., tabaiba

Gesneriaceae, Gesneria Family

710. Gesneria pedunculosa (DC.) Fritsch, árbol de navidad

\section{Guttiferae, Mangosteen Family}

165. Rheedia portoricensis Urban, palo de cruz

Lauraceae, Laurel Family

329. Licaria brittoniana Allen \& Gregory, canelón

334. Nectandra sintenisii $\mathrm{Mez}$, laurel amarillo

49. Ocotea moschata (Meissn.) Mez, nuez moscada

\section{Leguminosae, Legume Family}

354. Acacia anegadensis Britton, Anegada acacia. Anegada only.

\section{Magnoliaceae, Magnolia Family}

34. Magnolia portoricensis Bello, jagüilla

35. Magnolia splendens Urban, laurel sabino

\section{Malpighiaceae, Malpighia Family}

420. Byrsonima wadsworthii Little, almendrillo

423. Malpighia infestissima (A. Juss.) A. Rich., cowhage-cherry

\section{Malvaceae, Mallow Family}

151. Montezuma speciosissima Sessé \& Moc., maga

\section{Melastomataceae, Melastome Family}

196. Calycogonium squamulosum Cogn., jusillo

197. Heterotrichum cymosum (Wendl.) Urban, camasey peludo
605. Miconia pachyphylla Cogn., camasey racimoso

611. Miconia sintenisii Cogn., camasey

614. Miconia thomasiana DC., camasey tomaso

619. Tetrazygia biflora (Cogn.) Urban, camasey

621. Tetrazygia urbanii Cogn., camasey

Moraceae, Mulberry Family

294. Ficus stahlii Warb., jagüey

Myrsinaceae, Myrsine Family

635. Wallenia pendula (Urban) Mez, jacanillo

Myrtaceae, Myrtle Family

185. Calptranthes krugii Kiaersk., limoncillo

564. Eugenia borinquensis Britton, guayabota de sierra

568. Eugenia eggersii Kiaersk., guasábara

577. Eugenia sessiliflora Vahl

191. Eugenia stahlii (Kiaersk.) Krug \& Urban, guayabota

581. Eugenia xerophytica Britton

Nyctaginaceae, Four-o'clock Family

317. Neea buxifolia (Hook. f.) Heimerl.

Ochnaceae, Ochna Family

509. Ouratea littoralis Urban, abey amarillo

Palmae, Palm Family

267. Coccothrinax alta (O. F. Cook) Beccari, palma de abanico, tyre palm

9. Roystonea borinquena O. F. Cook, palma real, royal palm, Puerto Rico royalpalm

10. Sabal causiarum (O. F. Cook) Beccari, palma de sombrero, Puerto Rico palmetto

Piperaceae, Pepper Family

280. Piper blattarum Spreng., higuillo

Polygonaceae, Buckwheat Family

211. Coccoloba pyrifolia Desf., uvera

313. Coccoloba sintenisii Urban, uvero de monte

Rosaceae, Rose Family

57. Hirtella rugnj Pers., icaquillo

Rubiaceae, Madder Family

239. Antirhea obtusifolia Urban, quina

733. Machaonia portoricensis Baill., alfilerillo

743. Psychotria maleolens Urban, cachimbo de gato

744. Psychotria maricaensis Urban, cachimbo de Maricao

746. Rondeletia inermis (Spreng.) Krug \& Urban, cordobancillo

248. Rondeletia portoricensis Krug \& Urban, juan tomás 
Sapindaceae, Soapberry Family

142. Thouinia portoricensis Radlk., serrasuela

143. Thouinia striata Radlk., ceboruquillo

Sapotaceae, Sapodilla Family

639. Chrysophyllum pauciflorum Lam., caimito de perro

212. Micropholis garciniifolia Pierre, caimitillo verde

Simaroubaceae, Ailanthus Family

411. Simarouba tulae Urban, aceitillo cimarrón

Theaceae, Tea Family

515. Ternstroemia stahlii Krug \& Urban, mamey del cura

Thymelaeaceae, Mezereon Family

177. Daphnopsis philippiana Krug \& Urban, majagua brava

\section{Rare Species Native Beyond (Nonendemic)}

Besides the endemics, about 100 species native also beyond or outside of Puerto Rico and the Virgin Islands, or nonendemic species, could be classed as rare there. The list below has been revised and expanded from the 77 cited by number in the second volume $(15, \mathrm{p} .18)$. After further field work, 5 species were removed. Also, 16 from that volume, 10 from the first volume, and 2 others have been added as rare.

More than two-thirds of the 100 rare nonendemic tree species are protected within public forests and parks. These 22 species have been recorded from the Caribbean National Forest: 42, 52, 56, 254, 300, 325, 339, 341, 353, $417,421,450,489,510,511,528,529,593,599,683,695$, and 724 .

These 15 species are very rare and should be watched: $285,306,322,324,335,449,458,476,477,558,592,593$, 663,719 , and 730 . Four species are becoming scarce in Puerto Rico because of their useful woods: 93, 94, 101, and 108.

Six are absent from Puerto Rico. Three at Mona Island only are 268,492 , and 745 . Two in the Virgin Islands but not Puerto Rico are 409 and 449. One, 306, is from Culebra, Vieques, St. Thomas, and St. Croix.

Nearly all these 100 rare nonendemics are border or peripheral species. They have wider distribution beyond Puerto Rico and the Virgin Islands to other islands or even the continent. Thus, disappearance on these islands could not cause extinction. Nevertheless, the accessible trees here merit protection as needed. Most of these tree species are not native within continental United States.

\section{Annonaceae, Annona Family}

322. Oxandra lanceolata (Sw.) Baill., haya prieta, lancewood

324. Rollinia mucosa (Jacq.) Baill., anón cimarrón. Very rare.

\section{Aquifoliaceae, Holly Family}

458. Ilex cassine L., dahoon. Very rare.

460. Ilex guianensis (Aubl.) Kuntze, macoucoua

\section{Bignoniaceae, Bignonia Family}

703. Enallagma latifolia (Mill.) Small, higüerita, black-calabash

\section{Boraginaceae, Borage Family}

676. Rochefortia acanthophora (DC.) Griseb., juso

676.1. Rochefortia cuneata Sw., espino

677. Tournefortia filiflora Griseb., nigua

Buxaceae, Box Family

453. Buxus laevigatus (Sw.) Spreng.

\section{Cactaceae, Cactus Family}

539. Opuntia moniliformis (L.) Haw. Destroyed by cactus moth.

\section{Cunoniaceae, Cunonia Family}

56. Weinmannia pinnata $\mathrm{L}$., oreganillo

\section{Cyatheaceae, Tree-fern Family}

254. Cyathea wilsonii (Hook.) Proctor, helecho gigante, tree-fern

\section{Ebenaceae, Ebony Family}

648. Diospyros revoluta Poir., guayabota

Elaeocarpaceae, Elaeocarpus Family

494. Sloanea amygdalina Griseb.

Erythroxylaceae, Coca Family

392. Erythroxylum rufum Cav.

393. Erythroxylum urbanii O. E. Schulz

\section{Euphorbiaceae, Spurge Family}

438. Drypetes ilicifolia Krug \& Urban, encinillo 446.1. Phyllanthus cuneifolius (Britton) Croizat 449. Sapium caribaeum Urban. Perhaps extinct on St. John but found on Tortola.

450. Sapium jarnaicense Sw., tabaiba

\section{Flacourtiaceae, Flacourtia Family}

528. Laetia procera (Poepp. \& Endl.) Eichl., talantrón 529. Lunania buchii Urban

531. Prockia crucis L.

535. Xylosma schaeferioides A. Gray 


\section{Hernandiaceae, Hernandia Family}

52. Hernandia sonora L., mago

Icacinaceae, Icacina Family

476. Mappia racernosa Jacq. Very rare.

477. Ottoschulzia rhodoxylon (Urban) Urban, palo de rosa. Not collected in Puerto Rico in recent years but located in Hispaniola as a range extension. Proposed as endangered $(I)$.

\section{Juglandaceae, Walnut Family}

285. Juglans jamaicensis C. DC., nogal, West Indian walnut

\section{Lauraceae, Laurel Family}

325. Aniba bracteata (Nees) Mez, canelillo

42. Beilschmiedia pendula (SW.) Benth. \& Hook. f., guajón

44. Licaria triandra (Sw.) Kosterm., palo de misanteco, Gulf licaria

335. Ocotea foeniculacea Mez, palo santo. Very rare.

338. Persea krugii Mez, canela

339. Persea urbaniana Mez, aguacatillo

341. Phoebe montana (Sw.) Griseb., avispillo

Leguminosae, Legume Family

375. Cynometra portoricensis Krug \& Urban, oreganillo (Also Dominican Republic.)

66. Piptadenia peregrina (L.) Benth., cojóbana. Rare, very local. Apparently introduced, perhaps by prehistoric Indians.

\section{Malpighiaceae, Malpighia Family}

417. Bunchosia glandulifera (Jacq.) H.B.K., café falso

421. Malpighia fucata Ker, palo bronco

424. Malpighia linearis Jacq., stingingbush

Malvaceae, Mallow Family

495.1. Hibiscus clypeatus L.

\section{Melastomataceae, Melastome Family}

592. Clidemia umbrosa (Sw.) Cogn. Very rare.

593. Conostegia hotteana Urban \& Ekman. Very rare.

597. Henriettea triflora (Vahl) Alain

599. Miconia affinis DC., camasey -

604. Miconia ottoschulzii Urban \& Ekman

606. Miconia punctata (Desr.) D. Don, camasey

615. Mouriri domingensis (Tuss.) Spach, murta

618. Tetrazygia angustifolia (Sw.) DC., stinking-fish

\section{Meliaceae, Mahogany Family}

108. Cedrela odorata L., cedro hembra, Spanishcedar. Commercial (threatened).
Menispermaceae, Moonseed Family

318. Hyperbaena laurifolia (Poir.) Urban

Moraceae, Mulberry Family

297. Pseudolinedia spuria (Sw.) Griseb., negra lora

Myricaceae, Waxmyrtle Family

283. Myrica cerifera L., cerero, southern bayberry

Myrtaceae, Myrtle Family

558. Calyptranthes zuzygium (L.) Sw., myrtle-of-theriver

569. Eugeria glabrata (Sw.) DC.

574. Eugenia procera (Sw.) Poir., hoja menuda

Nyctaginaceae, Four-o'clock Family

315. Guapira discolor (Spreng.) Little, barrehorno

Ochnaceae, Ochna Family

508. Ouratea ilicifolia (DC.) Baill.

510. Ouratea striata (v. Tiegh.) Urban

Olacaceae, Olax Family

306. Schoepfia schreberi J. F. Gmel. Very rare, islands east of Puerto Rico.

Oleaceae, Olive Family

653. Forestiera eggersiana Krug \& Urban

654. Forestiera rhamnifolia Griseb.

660. Linociera axilliflora Griseb., hueso

663. Linociera ligustrina Sw., hueso. Very rare.

Palmae, Palm Family

268. Pseudophoenix sargentii $\mathrm{H}$. Wendl., Florida cherrypalm.

Piperaceae, Pepper Family

281. Piper tuberculatum Jacq., higuillo

Polygonaceae, Buckwheat Family

314. Coccoloba tenuifolia L.

Rhamnaceae, Buckthorn Family

489. Rhamnus sphaerosperma Sw., West Indian buckthorn

492. Ziziphus taylorii (Britton) M. C. Johnst. Mona only.

Rosaceae, Rose Family

353. Prunus occidentalis Sw., almendrón, West Indies laurelcherry

Rubiaceae, Madder Family

719. Chione seminervis Urban \& Ekman

720. Chione venosa (Sw.) Urban, Martín Avila 
723. Exostema ellipticum Griseb., plateado

724. Exostema sanctae-luciae (Kentish) Britten

730. Guettarda valenzuelana A. Rich., cucubano de monte

735. Palicourea barbinervia DC., bálsamo real, showy palicourea

740. Phialanthus myrtilloides Griseb.

745. Psychotria nutans Sw., cachimbo de Mona. Mona only.

747. Rondeletia pilosa Sw., cordobancillo peludo. Not rare in Virgin Islands.

\section{Rutaceae, Rue Family}

394. Amyris balsamifera L., teilla, balsam amyris.

Not found.

403. Zanthoxylum bifoliolatum Leonard

101. Zanthoxylum flavum Vahl, acetillo, yellowsanders, yellow-heart

406. Zanthoxylum spinifex (Jacq.) DC., niaragato

Sapindaceae, Soapberry Family

479. Allophylus racemosus Sw., quiebrahacha

Sapotaceae, Sapodilla Family

638. Chrysophyllum bicolor Poir., caimitillo, wild cainit

643. Manilkara jaimiqui (C. Wright) Dubard, jaimiqui, wild-dilly

645. Pouteria dictyoneura (Griseb.) Radlk.

646. Pouteria hotteana (Urban \& Ekman) Baehni

Simaroubaceae, Ailanthus Family

409. Picrasma antillana (Eggers) Urban, bitter-ash.

Virgin Islands, but not Puerto Rico.
410. Picrasma excelsa (Sw.) Planch., palo amargo, bitterwood

\section{Solanaceae, Nightshade Family}

695. Solanum antillarum O. E. Schulz

698. Solanum polygamum Vahl, cakalaka-berry. Uncommon in Virgin Gorda.

\section{Theaceae, Tea Family}

511. Cleyera albopunctata (Griseb.) Krug \& Urban

514. Ternstroemia peduncularis DC.

\section{Theophrastaceae, Theophrasta Family}

630. Jacquinia revoluta Jacq., barbasco

\section{Urticaceae, Nettle Family}

300. Urera caracasana (Jacq.) Gaud., ortiga colorada, stinging nettle. Not found in recent years and possibly extinct in Puerto Rico.

\section{Verbenaceae, Verbena Family}

678. Aegiphila martinicensis Jacq., capaillo

683. Cornutia pyramidata $\mathrm{L}$.

\section{Zygophyllaceae, Caltrop Family}

93. Guaiacum officinale L., guayacán, common lignumvitae. Common, but commercial (threatened).

94. Guaiacum sanctum L., guayacán blanco, holywood lignumvitae. Common, but commercial (threatened). 


\section{Endemic Species of Virgin Islands}

Relatively few, about 26, of the 142 species of endemic trees native in Puerto Rico and the Virgin Islands grow wild in one or more of the Virgin Islands (15, p. 16-17). These small islands of mostly low altitude have seasonal and dry lowland forests of wide distribution. The small number of local species is related to lack of isolation.

Only 5 tree species are confined to the Virgin Islands, that is, not native elsewhere, and another was found also on Culebra. These species of very restricted area on privately owned lands merit additional protection. One, Acacia anegadensis Britton, is common locally. The others are listed under list 2, Endemic Species Needing Protection. Another, 552, Calyptranthes kiaerskovii Krug \& Urban, the only endemic of Tortola, was named from a sterile specimen and has been noted under extinct species. The list follows:

354. Acacia anegadensis Britton, Anegada acacia, Leguminosae, legume family. A small tree known only from Anegada, British Virgin Islands, where it is common near the west end of that island. This distinctive local species without close relatives is the only tree species endemic to the British Virgin Islands alone. It was later placed by its author in a segregate genus, Fishlockia. (Croton fishlockii Britton is an endemic shrub discovered on Gorda Peak, Virgin Gorda. It has been found also on the top of Great Camanoe, a small island near Tortola, by Woodbury.)

425. Malpighia pallens Small, stingingbush, Malpighiaceae, malpighia family. St. Croix and Buck Island, including Buck Island Reef National Monument.

498. Sida eggersii E. G. Baker, Malvaceae, mallow family. Tortola and Jost Van Dyke (1 tree), British Virgin Islands. Collected twice on Culebra in 1906 and 1913 and apparently extinct there.

557. Calyptranthes thomasiana Berg, Myrtaceae, myrtle family. St. Thomas and Vieques.

The 22 tree species repeated below are known only from Puerto Rico and also 1 or more of the Virgin Islands, as stated. The ranges may be extended slightly after further field work on small islands.

\section{Aquifoliaceae, Holly Family}

466. Ilex urbaniana Loes., cuero de sapo. Tortola.

\section{Boraginaceae, Borage Family}

674. Cordia rickseckeri Millsp., San Bartolomé, manjack. Palominos, Culebra, Vieques, St. Croix, St. Thomas, St. John, Jost Van Dyke, Tortola, Virgin Gorda.

\section{Buxaceae, Box Family}

454. Buxus vahlii Baill. St. Croix.

\section{Celastraceae, Bittersweet Family}

470. Maytenus cymosa Krug \& Urban. Piñeros, Vieques, St. Croix, St. Thomas, Virgin Gorda.
Ericaceae, Heath Family

627. Lyonia rubiginosa (Pers.) G. Don. St. Thomas.

\section{Euphorbiaceae, Spurge Family}

435. Croton rigidus (Muell. Arg.) Britton, adormidera. Culebra, Culebrita, Vieques, St. Croix and Buck Island, St. Thomas, St. John, Tortola, Virgin Gorda.

\section{Leguminosae, Legume Family}

380. Erythrina eggersii Krukoff \& Moldenke, piñón espinoso, cockspur. Vieques, St. Croix, St. Thomas, St. John.

88. Pictetia aculeata (Vahl) Urban, tachuelo, fustic. Culebra, Vieques, St. Croix, St. Thomas, St. John, Tortola, Virgin Gorda, Anegada.

389. Sabinea florida (Vahl) DC., retama, wattapania. Culebra, Vieques, St. Thomas, St. John, Tortola, Virgin Gorda.

\section{Malpighiaceae, Malpighia Family}

423. Malpighia infestissima (A. Juss.) A. Rich., cowhage-cherry. Maguey Island, Vieques, Culebra, Water Island, St. Thomas, St. John, Virgin Gorda, Anegada.

\section{Melastomataceae, Melastome Family}

614. Miconia thomasiana DC., camasey tomaso. Tortola. Reported and named from St. Thomas, apparently in error.

\section{Myrtaceae, Myrtle Family}

577. Eugenia sessiliflora Vahl. Vieques, Culebra, St. Croix, Water Island, St. Thomas, Tortola, Virgin Gorda. 590. Psidium amplexicaule Pers., mountain guava. St. Thomas, St. John, Tortola, Virgin Gorda.

Nyctaginaceae, Four-o'clock Family

317. Neea buxifolia (Hook. f.) Heimerl. Piñeros, Culebra, St. Thomas, St. John.

Ochnaceae, Ochna Family

509. Ouratea littoralis Urban, abey amarillo. St. Thomas, Virgin Gorda.

\section{Palmae, Palm Family}

4. Acrocomia media O. F. Cook, cocozo, pricklypalm, Puerto Rico acrocomia. St. Thomas.

267. Coccothrinax alta (O. F. Cook) Beccari, palma de abanico, tyre-palm. Vieques, Cubebra, St. Croix (3 trees), St. Thomas, St. John, Virgin Gorda.

9. Roystonea borinquena O. F. Cook, palma real, royal palm, Puerto Rico royalpalm. Vieques, St. Croix.

\section{Rhamnaceae, Buckthorn Family}

486. Reynosia guama Urban, guamá. St. Thomas, St. John, Jost Van Dyke, Virgin Gorda. 


\section{Rutaceae, Rue Family}

407. Zanthoxylum thomasianum (Krug \& Urban) Krug \& Urban. St. Thomas, St. John.

\section{Sapotaceae, Sapodilla Family}

639. Chrysophyllum pauciflorum Lam., caimito de perro. Vieques, St. Croix, St. Thomas, St. John.

644. Manilkara pleeana (Pierre) Cronq., zapote de costa. Vieques, St. John, Tortola. 


\section{Relationships of the Endemic Species}

The rare and local tree species of Puerto Rico and the Virgin Islands can serve as a background for studies of the origin and relationships of the plant life. Endemic species, having developed in isolation from relatives elsewhere, are particularly significant in such studies. Some general, preliminary observations on the endemic species and endemic genera may be mentioned here.

An analysis of the geographic distribution of the native tree species of these islands was presented in the second volume $(15, \mathrm{p} .15)$. According to their patterns of geographic distribution, the species may be arranged in three main groups: (1) More than two-fifths (229 species, $41.9 \%$ ) also on the continent, mainly South America but also Central America (or Mexico or Florida); (2) onethird (177 species, 32.4\%) in West Indies but not on the continent; and (3) one-fourth (141 species, 25.7\%) endemic to Puerto Rico and the Virgin Islands. The main source of the original immigrants or ancestral species was South America, though Central America was another.

The endemic species in that compilation of 547 native tree species were grouped further as follows:

Endemic to Puerto Rico and/or Virgin Islands, 141 species, $25.7 \%$.

Puerto Rico and Virgin Islands only, 21 species, $3.8 \%$.

Puerto Rico and adjacent island only, 6 species, $1.1 \%$.

Puerto Rico only, 109 species, $19.9 \%$.

Virgin Islands only, 5 species, $0.9 \%$.

The study of the relationships of the trees of the Luquillo Mountains shows what could be done on a larger scale (7). Some similarities among endemics and nonendemics were indicated. For example, 2 or more related endemic species apparently were derived from the same ancestor or original immigrant. Paired species were observed on mountains, which are climatic islands within the larger island. Thus, Magnolia splendens is endemic to Luquillo Mountains, and $M$. portoricensis to the central and western mountains.

The endemic trees of Puerto Rico and the Virgin Islands, as listed here, total 142 species. These are grouped into 94 genera and 50 plant families. In comparison, all native trees total 551 species in 273 genera and 85 plant families.

Endemic tree species are more common in some genera than others. Possibly some groups evolve more rapidly than others. More endemics may be expected in large genera also.

Genera with the greatest numbers of endemic tree species are as follows: Eugenia 10; Calyptranthes and Miconia 5; Ternstroemia 4; and Antirhea, Brunfelsia, Coccoloba, Ilex, Mayterus, Tabebuia, and Tetrazygia 3 each. Fifteen other genera have 2 endemic tree species, while 68 have only 1 . Several genera also contain related endemics that are shrubs. In comparison, the largest genera in number of native tree species are Eugenia 23, Miconia 17, and Coccoloba 12.

Plant families with the most endemic tree species are: Myrtaceae, 19 species in 5 genera; Melastomataceae, 12 species in 6 genera; Palmae, 7 species in 7 genera; Sapotaceae, 5 species in 5 genera; Solanaceae, 5 species in 3 genera; and Theaceae, 5 species in 2 genera.

The palm family, Palmae, apparently is of great age in Puerto Rico. The 10 native genera are represented by a single species each, and 7 have changed after arrival into species not found elsewhere.

\section{Species New to Science}

Very few tree species new to science have been found in recent years in Puerto Rico and none in the Virgin Islands, as noted in the second volume (15, p. 17). After completion of the flora by Britton and Wilson (2), only the following 8 tree species have been published by later authors as new:

Linociera lıoldridgii Camp \& Monachino (Lloydia 2: 223. 1939)

Myrica lıoldridgeana Lundell (Contrib. Univ. Mich. Herbarium 7: 5. 1942.)

Licaria brittoniana Allen \& Gregory (Brittonia 7: 267. 1951)

Byrsonima wadsworthii Little (Phytologia 4: 417, fig. 1953)

Calptranthes luquillensis Alain (Bull. Torrey Bot. Club 90: 189. 1963)

Eugeria haematocarpa Alain (Bull. Torrey Bot. Club 90: 190. 1963)

Plialanthus grandifolius Alain (Bull. Torrey Bot. Club 92: 302. 1965)

Alsoplila bryophila Tryon (Rhodora 74: 443, figs. 9-10. 1972)

All 8 are endemic to Puerto Rico. None needs special protection. These 2 are in list 3, Endemic Species To Be Watched: Calyptranthes luquillensis, Eugenia haematocarpa. These 3 are in list 4, Other Rare Endemic Species: Linociera holdridgii, Myrica holdridgeana, Plialantlus grandifolius. The other 3 are in list 5, Common Endemic Species: Licaria brittoniana, Byrsonima wadsworthii, Alsophila bryopliila. Several other new species described as shrubs may be observed later to attain tree size.

\section{Endemic Genera}

Several endemic tree species of Puerto Rico are so different from others of their plant families that they have been placed in new genera. These species have changed sufficiently from their original immigrant or ancestral species to merit a new generic as well as specific name. 
The following summary of 8 endemic tree genera reduced to 1 is revised from an earlier article (7).

Four currently accepted genera with endemic tree species were named from Puerto Rico and another from both the Virgin 1slands and Puerto Rico. However, a second species discovered later on another island eliminated 3 endemic genera. Two other segregate genera have been reduced to synonymy, and another merits further study. Only Montezuma is now limited to Puerto Rico, though Stahlia is almost so.

Montezuma Sessé \& Moc. (1824; Malvaceae, mallow family) is the best known of these 8 genera. It was named for the Aztec ruler in Mexico and erroneously confused with Mexican collections. This genus was designated independently as Maga Urban (1912), and a second species from Cuba has since been placed in a separate genus. The only species, 151, Montezuma speciosissima Sessé \& Moc., maga, with very large red flowers, is native in the moist limestone forest region of Puerto Rico. It has been planted extensively for ornament and shade in other parts of the island and has been introduced through the West Indies to southern Florida. Closely related to the genus Thespesia and named simultaneously $T$. grandiflora DC.

Stahlia Bello (1881; Leguminosae, legume family) has a single species, 79, Stahlia monosperma (Tul.) Urban, cóbana negra, first distinguished in 1844. It is a small or medium-sized tree rare in coastal forests of southwestern and southeastern Puerto Rico and in Vieques. Afterwards found near Macao, eastern Dominican Republic, it technically is no longer endemic.

Pleodendron v. Tieghem (1899; Canellaceae, canella family) was based on 522, Pleodendron macranthum (Baill.) v. Tieghm., chupacallos, first named in 1882. Small or medium-sized tree, very rare in forests in lower Luquillo Mountains and moist limestone regions. A second species, P. ekmanii Urban (1928), was added from Haiti. Incidentally, this genus has been in Puerto Rico a long time, according to Graham and Jarzen (4). They reported finding pollen of Oligocene age.

Goetzea Wydler (1830; Solanaceae, nightshade family) is represented by 694, Goetzea elegans Wydler, matabuey. Small tree, very rare and local, known only from a few places in the moist limestone and moist coastal forests. Worthy of cultivation for its showy orange flowers and orange fruit. A second species, $G$. ekmanii O. E. Schulz (1933), was named from the Dominican Republic and Haiti. Airy Shaw (30) established the distinct family Goetzeaceae for a small relic group of uncertain affinities with 5 genera and 7 species in Mexico and the West Indies. This Puerto Rican species may be the easternmost.

Sabinea DC. (1825; Leguminosae, legume family) was based on 389, S. florida (Vahl) DC., retama, wattapania, named from St. Thomas in 1793. Shrub or small tree locally common in northern Puerto Rico, Culebra, Vieques, and Virgin Islands. Sparingly planted as an ornamental for the masses of bluish purple flowers. This genus now has 2 more species, a shrub endemic to central and western Puerto Rico, S. punicea Urban, and another shrub in Dominica.

Menendezia Britton (1925; Melastomataceae, melastome family) was set up from the genus Tetrazygia Rich. for 3 endemic tree species of Puerto Rican mountains. This segregate was not accepted in the second volume.

Fishlockia Britton \& Rose (1928; Leguminosae, legume family) was created for a single species endemic to Anegada, Acacia anegadensis Britton (1916). This segregate was not accepted afterwards.

Cybianthopsis (Mez) Lundell (Wrightia 4: 68. 1968; Myrsinaceae, myrsine family) was elevated from a subgenus distinguished in 1901 for 1 endemic tree species of Luquillo Mountains, Grammadenia sintenisii (Urban) Mez or Cybianthopsis sintenisii (Urban) Lundell. Further study seems desirable before acceptance of this segregate.

\section{Trees Absent From Puerto Rico}

Certain families and genera of trees widespread on the continent are absent from Puerto Rico and the Virgin Islands, or poorly represented there, as noted previously (7). Apparently these groups have not been successful in crossing the ocean barriers, though some may have become extinct after arrival. Accordingly, Puerto Rico, like oceanic islands in general, has a relatively poorer flora than corresponding continental areas. Islands, however, compensate by having greater numbers of endemics.

Puerto Rico has 85 plant families with native tree species. In comparison, Costa Rica in Central America has about 106 and Venezuela in northern South America has about 100 . Mexico has a high number, about 106, because several north temperate families are present.

Most of the missing plant families have relatively few species and perhaps less chance of reaching the island. Among those without native tree species in Puerto Rico are Humiriaceae, Lecythidaceae, Monimiaceae, Myristicaceae, Proteaceae, and Vochysiaceae. The family Tiliaceae has no native tree species but is represented by 2 genera of shrubs and herbs. There are only 3 native species of Bombacaceae.

Puerto Rico's only native conifer, Podocarpus coriaceus (Podocarpaceae), is of South American origin. Northern conifers are absent. The genera Pinus (Pinaceae) and Juniperus (Cupressaceae) are native in continental United States, Bahamas, Cuba, and Hispaniola but not as far as Puerto Rico. 
Graham and Jarzen (4), studying a deposit of Oligocene age in western Puerto Rico, were able to identify to genus 44 out of 165 morphological types of fossil pollen and spores, some not there now. These temperate tree genera were listed: Engelhardia, Fagus, Liquidambar, Nyssa, and Salix. These tropical American genera there about 45 million years ago are absent now: Bernoullia, Bombax, Catostemma, Jacaranda, Pelliciera, and Tetrorchidium. The first 3 are in Bombacaceae, mentioned above as a family poorly represented. 


\section{Public Forests and Parks}

Most rare and local tree species of Puerto Rico and the Virgin Islands are protected within the boundaries of one or more public forests and parks (15, p. 23-28, maps 4 and 2). The system of 15 public forests is one of Puerto Rico's most valuable natural resources. Four National Parks have been established in the Virgin Islands.

The Caribbean National Forest, formerly known also as the Luquillo Experimental Forest, embraces most of the Luquillo Mountains of northeastern Puerto Rico. It was established in 1903 from former Spanish crown lands and now contains 28,000 acres $\left(43^{3} / 4 \mathrm{mi}^{2}\right.$ or $\left.11,300 \mathrm{ha}\right)$. It is administered by the Forest Service, United States Department of Agriculture, with headquarters at Rio Piedras.

Fourteen Commonwealth Forests (Bosques Estatales) totaling about 60,000 acres $(24,000 \mathrm{ha})$ are well distributed over the island. Unalienated forest lands in the mangroves at Guánica and Maricao and on Mona Island were the first Commonwealth Forests. Others were acquired some years ago under a Federal program for purchase of marginal lands, primarily to protect soil and water values of mountain watersheds. The Puerto Rico Department of Natural Resources administers these Commonwealth Forests as well as Mona Island, which is classed under forest lands.

These public forests of Puerto Rico range from mangroves along the seacoast to the highest peaks of the Central Cordillera and Luquillo Mountains and include the driest and wettest areas. They contain representative areas of the major natural ecosystems and nearly all the remaining virgin forests.

Another public forest, the Estate Thomas Experimental Forest of 149 acres (60 ha), is located on St. Croix, U.S. Virgin Islands. It is administered by the Institute of Tropical Forestry.

Four National Parks have been established in the Virgin Islands and preserve representative undisturbed areas of seasonal and dry forests. Additional rare and local trees are protected there. The National Park Service, U.S. Department of the Interior, administers the two in the U.S. Virgin Islands. Virgin Islands National Park, established in 1956, covers almost two-thirds of the island of St. John, a gross area of 14,418 acres (5,835 ha) containing examples of nearly all species of native trees. Buck Island Reef National Monument, designated in 1961, contains 176 acres (71 ha) of protected forest vegetation.

In the British Virgin Islands, the National Parks Trust administers two National Parks. Sage Mountain National Park of about 50 acres (20 ha) contains a unique mountain forest on the highest peak in the Virgin Islands. Gorda Peak National Park preserves undisturbed forest lands on Virgin Gorda.

The authors with Frank $\mathrm{H}$. Wadsworth made special efforts to compile lists of the tree species of each public forest and park. The 2-volume reference cites for each native tree species the names of public forests and parks where it is found, preserved, and protected in its natural habitat. Only about 19 rare and endangered tree species were not found on any public forest or park $(15$, p. 16). From that reference a list of the rare and endemic trees could be compiled for each public forest and park.

Tree lists for a few of these areas have been published by the authors, as follows: Mona Island (5), Buck Island Reef National Monument (3l), Caribbean National Forest $(7,14)$, and Virgin Gorda (16).

The Caribbean National Forest has the greatest concentration of rare and endemic trees, about 90 species, as noted above. Other public forests preserve large numbers of endemic tree species but have almost no local endemics. The earlier compilation $(15$, p. 16) had these totals of endemic tree species within public forests: Maricao 52, Toro Negro 45, Carite 38, Susúa 24, and Guánica 11 . 


\section{Economic Importance of Endemic Species}

The economic possibilities of endemic tree species merit special attention. Many of these endemic trees are poorly known, except to scientists and local residents. Some may have unknown values. Wider planting later would provide further insurance against extinction.

The 2-volume reference contains Special Lists $(12, \mathrm{p}$. $19-20 ; 15$, p. 32-33) of tree species with distinctive characters, special features, and uses. There are planting lists of trees for particular purposes. Endemic species can be found under their numbers.

Many endemic trees have advantages when planted outside their native ranges in being resistant to disease and insect pests of unrelated species and in being separated from their own parasites. Some species may have special chemical compounds of commercial importance, possibly medicines, and merit screening tests or sampling. Others may serve in tree breeding, such as production of superior hybrids with related species elsewhere.
The endemic trees are mainly small or shrubby, but a few attain large size. Several species of native trees have woods adapted to special uses. Magnolia splendens, laurel sabino, has a very attractive olive green heartwood when freshly cut, later becoming brown. The wood is used almost entirely for furniture and cabinetwork. Other endemics of Luquillo Mountains with useful timbers in limited supply include Calycogonium squamulosum, jusillo; Eugenia stahlii, guayabota; and Micropholis garciniifolia, caimitillo verde.

Various endemic tree species are recommended for shade and ornament. Several have large showy flowers with a wide display of coloration. Maga (Montezuma speciosissima), with large red flowers, decorates the cover of the first volume. Violeta or violet-tree (Polygala cowellii), on the covers of the second volume and this report, has masses of blossoms as named. 


\section{Puerto Rico and Hawaii Compared}

The importance of the rare and endemic trees of Puerto Rico and the Virgin Islands can be understood and evaluated by a comparison with those of the Hawaiian Islands in table 1. The Commonwealth of Puerto Rico and the State of Hawaii have several characteristics in common. Both are located in the northern tropics at about the same latitude, and both became territories of the United States 1898.

The "Big Island" of Hawaii (area 4,038 $\mathrm{mi}^{2}, 10,458$ $\mathrm{km}^{2}$ ) is slightly larger than Puerto Rico (area $3,435 \mathrm{mi}^{2}$, $8,897 \mathrm{~km}^{2}$ ). The Hawaiian archipelago also embraces 7 smaller islands with a total area of 2,411 square miles $\left(6,244 \mathrm{~km}^{2}\right)$, and scattered isles. In contrast, the U.S. Virgin Islands, purchased from Denmark in 1917, and the British Virgin Islands have a combined area of only about 200 square miles $\left(518 \mathrm{~km}^{2}\right)$.

The Hawaiian Islands are the most isolated in the world, near the center of the largest ocean and farthest from the continents. North America, the nearest continent, is 2,400 miles $(3,862 \mathrm{~km})$ to the northeast at California and slightly more at southern Alaska. These oceanic islands originated, like Puerto Rico and the Virgin Islands, as submarine volcanoes from the ocean floor but much later, about 5 to 10 million years ago. The "Big Island" perhaps only a million years old, is the largest and youngest. Its highest peaks are Mauna Kea (altitude 13,796 ft, 4,205 m), the State's loftiest, and Mauna Loa (altitude 13,677 ft, 4,169 m), which has ac- tive craters and occasional lava flows. Thus, the Hawaiian Islands have very diverse geography, climate, and vegetation.

The native trees of the Hawaiian Islands are unique, different from those everywhere else in the world. Seeds of the ancestral trees were transported accidentally across long expanses of ocean. Some floated or came on driftwood, and others were carried by birds or the wind. Long-distance dispersal was a very rare occurrence, an accidental migration. After arrival and establishment, an immigrant species isolated from the distant parent probably changed and became a new species.

The latest compilation of the flora of Hawaii by St. John (20) accepted approximately 370 species of native trees. However, 60 years earlier, Rock $(18,19)$ described only about 230 species in his book "The Indigenous Trees of the Hawaiian Islands." The number could be revised and reduced perhaps to fewer than 300 through union of minor variations.

The native trees of Hawaii, 300-370 species, are grouped into 70 genera and 40 plant families. More than one-half belong to the 5 largest families: rue (Rutaceae), ginseng (Araliaceae), madder (Rubiaceae), palm (Palmae), and pittosporum (Pittosporaceae). Some familiar families of tropical trees are absent, for example, mahogany (Meliaceae), bombax (Bombacaceae), melastome (Melastomataceae), and bignonia (Bignoniaceae). There are no native conifers, figs (Ficus), or mangroves.

Table 1.-Comparison of rare native trees of Hawaii and Puerto Rico and the Virgin Islands

Native trees

Plant families with trees

Families with endemic species

Tree genera

Genera with endemic species

Endemic tree genera

Tree species

Named varieties

Island totals

Genera on 1 island

Species on 1 island

Nonendemic species

Rare nonendemic species

Endemic species

Percent of endemic species

Average number of endemic species per genus with endemic species

Species endemic to 1 island

Extinct species

Rare endemic species

Rare endemic species needing additional protection

Rare endemic species to be watched
Hawaii

Puerto Rico and the Virgin Islands

$\begin{array}{cc}40 & 85 \\ 39 & 50 \\ 70 & 273 \\ 66 & 94 \\ 17 & 1 \\ 300-370 & 551 \\ \text { Many } & \text { Very few } \\ 52-66 & \\ 84-165 & 271 \\ 11 & 539 \\ 1 & 409 \\ 289-359 & 100 \\ 96-97 \% & 142 \\ 4.4-5.4 & 25.8 \% \\ 236(?) & 1.5 \\ 21 & 106^{2} \\ ? & 0(?) \\ \text { About } 50 & 83 \\ 20 & 13 \\ \text { About } & 22\end{array}$

\footnotetext{
'Approximate totals by islands: Kauai, 65 genera and 134 species; Oahu, 66 and 165; Molokai, 55 and 90 ; Maui, 61 and 127 ; Lanai, 52 and $84 ;$ Hawaii, 61 and 119; and Puerto Rico, 271 and 539. Totals in Virgin Islands not available.

${ }^{2}$ Puerto Rico, species not found also on any smaller island.
} 
Other families are poorly represented, the palm family (Palmae) only by Prichardia, the laurel family (Lauraceae) by 2 species, and the flacourtia family (Flacourtiaceae) by 1 .

However, a few tropical tree species are widespread. For example, 2 species of Puerto Rico and the Virgin Islands are represented also on the American continent north to southern Florida (a variety of 1 also to southern Arizona) and reappear again in Hawaii: Sapindus saponaria L., wingleaf soapberry, and Dodonaea viscosa (L.) Jacq., hopbush.

Several significant conclusions can be made from the comparison in table 1 . The unique tree flora of the Hawaiian Islands is definitely poor or impoverished (and Puerto Rico slightly so). Hawaii has fewer than one-half as many plant families with trees as does Puerto Rico (40 in contrast to 85 ) and slightly more than one-fourth as many genera with trees ( 70 in contrast to 273 ).

The number of tree species in all Hawaiian Islands combined is somewhat lower than that in Puerto Rico and the Virgin Islands, about two-thirds if the named segregates are accepted ( 370 in contrast to 551) or slightly more than one-half if the number of species is conservatively treated as fewer than 300 .

The small number of tree species is more obvious when totals by islands are compared. The total on each of the 4 larger Hawaiian Islands (119-165) is only about onefourth to one-third as many as in Puerto Rico (539). (The relatively small Virgin Islands have low numbers not available individually.)

More striking contrasts are shown by comparison with local lists within Puerto Rico. The Caribbean National Forest in the Luquillo Mountains possesses 225 native tree species, as noted, more than any one of the Hawaiian Islands. Oahu, which has been thoroughly explored by botanists working from Honolulu during more than a century, has only about 165 tree species (including weak segregates). Kauai, the oldest island of the group, has 134, and Hawaii, the largest, only 119.

The percentage of endemism in Hawaii is the highest in the world. Nearly all the tree species are native only within that archipelago (96-97\%), while one-fourth the trees of Puerto Rico and the Virgin Islands are endemic $(25.8 \%)$. Of course, the total number of endemic tree species is greater in all the Hawaiian Islands combined (289-359) than in Puerto Rico and the Virgin Islands together (142), more than twice as many.

Even so, the more numerous endemic species of the Hawaiian Islands show somewhat less diversity among fewer genera (66 in contrast to 94) and fewer families (40 in contrast to 50). Obviously, in Hawaii each genus with endemic species has more species, about 5 , in contrast to 1.5 in Puerto Rico. However, the number is increased by a few large genera with many poorly defined species. Several of the closely related Hawaiian species (also named varieties) have become extinct ( 21 in contrast to 0?). Thus, Puerto Rico and the Virgin Islands have a somewhat richer or greater display of mostly unrelated, widely differing endemics.

On an island to island basis, Puerto Rico has almost as many endemic tree species as any one of the Hawailan Islands. Puerto Rico (with 539 species of native trees) has 136 of the 142 species endemic to Puerto Rico and the Virgin Islands combined, or 106 not found on any smaller island.

Hawaii has a large number of endemic tree genera, 17 (in 12 plant families), as compiled by Stone (22). Puerto Rico has only 1 , as noted above, apparently because several other old local genera have spread into other isles.

Endemic species may be "new," such as in large groups of closely related species of continuous ranges, or "old," of few species with separated ranges. Hawaii has several very large genera with many "new" endemics as well as others with few "old" endemics. The endemic tree species of Puerto Rico and the Virgin Islands, mostly 1 or 2 i.1 a genus, are "old," largely isolated, and not closely related.

Geographic distribution of the endemic tree species varies somewhat in the two island groups. For detailed comparison, species maps would be desirable. Apparently, the endemic tree species of Hawaii are somewhat scattered among different mountain peaks and ranges of several islands. In Puerto Rico, the endemic tree species are mostly concentrated within a few mountain areas of one island, especially the Luquillo Mountains and Central Cordillera. Most of Puerto Rico's endemic tree species grow wild within six public forests. In Hawaii, protection of the greater number of endemics would require a larger number of preserves.

The palm family, Palmae, offers a very interesting comparison. The relatively young Hawaiian Islands have a single genus of native palms. Pritchardia has 33 named species, "young"' and weak, scattered through several islands (a few other species elsewhere), though the number probably should be reduced to less than half. Puerto Rico, a very old island, has 10 species of native palms, each in a different genus, as already noted. Seven are endemic "old" species without relatives on the island. Thus, Puerto Rico has the greater display of endemic palms.

Only a few native tree species in all these islands appear to need additional protection. Many are rare, but most are within public forests. As classed here, rare endemic species needing protection (some could be proposed as endangered) total about 50 species in Hawaii and 17 in Puerto Rico and the Virgin Islands. Rare endemic species to be watched (some could be proposed as threatened) total about 20 species in Hawaii and 22 in these West Indian islands. 
Thus, Puerto Rico, a similar but much older island than Hawaii, has a richer tree flora, more well-defined tree species, and none apparently extinct. The endemic but impoverished tree flora of the young Hawaiian Islands is of special interest to students of evolution. However, other tropical areas, such as Puerto Rico, have richer and more varied tree floras and are more representative examples of tropical vegetation for education and research. 


\section{Discussion}

The native tree species of Puerto Rico and the Virgin Islands are perhaps as well known as those of any comparable area in tropical America. General distribution and abundance of each species are documented. Maps have been prepared for only 100 common species and would be useful for watching the others. Thus, an evaluation of the rare and local species, including endemics, can be made. Also, any needed measures for protection of endangered species against possible extinction can be recommended.

The endemic tree species of Puerto Rico and the Virgin Islands, about 142, have survived and persisted under intensive land use and widespread destruction and disturbance of some natural habitats. No endemic tree species is known to have become extinct. Many species are rare, partly because of habitat destruction, while others are scarce because of the limited area of their habitat. A rare species in a natural or virgin mountain forest can survive indefinitely, as long as its habitat remains undisturbed. Fortunately, relatively few native tree species of Puerto Rico and the Virgin Islands appear to be endangered (about 13) or threatened with extinction (about 21) and to need additional protection.

The list of species proposed as endangered should be kept small. A short list is relatively easy to learn, to administer, to support, and to gain acceptance by the public. Species of wide or scattered distribution may not require protection throughout their ranges. Also, under multiple use, other land values may be considered. A species of broad range perhaps could be classed both to be watched and proposed as threatened.

Limited distribution alone is insufficient justification for proposal of a species as endangered. Many tree species of Puerto Rico have a very local range, several within a few thousand acres (or hectares) in Luquillo Mountains. So long as their habitat remains undisturbed, these species would not be regarded as endangered.

The public forests of Puerto Rico and the Virgin Islands are the foundation of land management and forest conservation for the protection and preservation of rare plants and animals. Great credit is due the early foresters of the Forest Service for their foresight in acquiring public forests under a Federal program for purchase of marginal lands.

The 15 public forests in Puerto Rico and the 4 National Parks in the Virgin Islands (2 U.S. and 2 British) preserve representative areas of natural and near natural vegetation or ecosystems. These public lands contain natural habitats of most species of native trees and smaller plants. Within the Caribbean National Forest, the Baño de Oro Research Natural Area of 1,800 acres (728 ha) has been established. Additional natural areas could be designated within the other public forests to provide further protection of rare species.

The recommendations of the previously cited committee report, "Rare and Endangered Plants of Puerto Rico" (23), merit further consideration. 


\section{Summary}

Like other oceanic islands, Puerto Rico and the Virgin Islands are rich in rare and local plant species found nowhere else. The 2-volume illustrated reference on the trees of Puerto Rico and the Virgin Islands by the authors with Frank $\mathrm{H}$. Wadsworth contains a chapter entitled "Endemic, Rare, and Endangered Tree Species," which serves as a background (15).

This expanded report, one of a series on rare trees of the United States, groups the species of rare and endemic trees into lists and summarizes present occurrence. The Endangered Species Act of 1973 has directed attention to rare species grouped as extinct, endangered, and threatened. Separate lists were proposed for Puerto Rico and the Virgin Islands in 1978. There is also the committee report (23), "Rare and Endangered Plants of Puerto Rico."

Puerto Rico and the Virgin Islands have about 551 species of native trees, of which 539 are found on Puerto Rico. More than one-fourth, or 142, are known only from these islands (endemic). Endemic and rare species together, as listed in this report, total about 242 , more than two-fifths.

No endemic tree species of Puerto Rico and the Virgin Islands is known to have become extinct. However, a few border or peripheral species may have disappeared there.

About 83 endemic tree species are classed also as rare. Endemic tree species needing additional protection because they are very rare and limited in area and because they grow mostly on privately owned lands total only about 13. They have also been proposed as endangered. Endemic tree species to be watched or monitored total 22, which have also been proposed as threatened. About 61 other endemic tree species are classed as common or not rare.

Besides the endemics, 100 others also native beyond (nonendemic) are listed as rare and 15 of these as very rare and to be watched. Nearly all of these 100 are border or peripheral species of wider distribution.

Most of the rare and local trees of Puerto Rico and the Virgin Islands are protected within one or more of the 15 public forests and 4 National Parks.

Only about 26 species of these endemic trees grow wild in one or more of the Virgin Islands and only 5 of them are not native elsewhere.

The economic possibilities of endemic tree species deserve special attention. Some may have unknown values.

Puerto Rico has a richer tree flora than Hawaii, with more well-defined species (many rare), but with fewer endemics.

The recommendations of the committee report, "Rare and Endangered Plants of Puerto Rico," merit further consideration. 
(1) Ayensu, Edward S., and Robert A. DeFilipps.

1978. Endangered and theatened plants of the United States. 403 p. Smithsonian Institution and World Wildlife Fund, Inc.

(2) Britton, N. L., and Percy Wilson.

1923-30. Descriptive flora-Spermatophyta. Botany of Porto Rico and the Virgin 1slands. N.Y. Acad. Sci., Sci. Surv. Porto Rico Virgin Islands, vol. 5, 6.

(3) Gleason, H. A., and Mel. T. Cook.

1927. Plant ecology of Porto Rico. N.Y. Acad. Sci., Sci. Surv. Porto Rico Virgin 1slands 7: 1-173, illus.

(4) Graham, Alan, and David M. Jarzen.

1969. Studies in neotropical paleobotany. 1. the Oligocene communities of Puerto Rico. Mo. Bot. Gard. Ann. 56: 308-357.

(5) Little, Elbert L., Jr.

1955. Trees of Mona Island. Caribb. Forester 16: 36-53, illus.

(6) Little, Elbert L., Jr.

1969. Trees of Jost Van Dyke (British Virgin 1slands). USDA For. Serv. Res. Pap. 1TF-9, 12 p., illus. Institute of Tropical Forestry, Rio Piedras, Puerto Rico.

(7) Little, Elbert L., Jr.

1970. Relationships of trees of the Luquillo Experimental Forest. In A tropical rain forest; a study of irradiation and ecology at El Verde, Puerto Rico. Ch. B-3, p. B-47-58. Howard T. Odum and Robert F. Pigeon (editors). U.S. Atomic Energy Commission, Washington, D.C.

(8) Little, Elbert L., J $\mathrm{r}$

1975. Rare and local conifers in the United States. U.S. Dep. Agric. Conserv. Res. Rep. 19, 25 p., illus.

(9) Little, Elbert L., Jr.

1976. Rare tropical trees of South Florida. U.S. Dep. Agric. Conserv. Res. Rep. 20, 20 p., illus.

(10) Little, Elbert L., Jr.

1977. Rare and local trees in the National Forests. U.S. Dep. Agic. Conserv. Res. Rep. 21, 14 p.

(11) Little, Elbert L., Jr.

1978. Atlas of United States trees. Volume 5. Florida. U.S. Dep. Agric. Misc. Publ. 1361, 22 p., 268 maps.

(12) Little, Elbert L., Jr., and Frank H. Wadsworth.

1964. Common trees of Puerto Rico and the Virgin lslands. U.S. Dep. Agric., Agric. Handb. 249, 548 p., illus.

(13) Little, Elbert L., Jr., Frank H. Wadsworth, and José Marrero. 1967. Arboles comunes de Puerto Rico y las Islas Vírgenes. 827 p., illus. Editorial, Universidad de Puerto Rico, Rio Piedras, Puerto Rico.

(14) Little, Elbert L., Jr., and Roy O. Woodbury.

1976. Trees of the Caribbean National Forest, Puerto Rico. USDA For. Serv. Res. Pap. 1TF-20, 27 p. Institute of Tropical Forestry, Rio Piedras, Puerto Rico.

(15) Little, Elbert L., Jr., Roy O. Woodbury, and Frank H. Wadsworth.

1974. Trees of Puerto Rico and the Virgin Islands, second volume. U.S. Dep. Agric., Agric. Handb. 449, 1,024 p., illus.

(16) Little, Elbert L., Jr., Roy O. Woodbury, and Frank H. Wadsworth.

1976. Flora of Virgin Gorda (British Virgin 1slands). USDA For. Serv. Res. Pap. 1TF-21, 36 p., illus. Institute of Tropical Forestry, Rio Piedras, Puerto Rico.

(17) Nevling, Lorin 1., Jr., and Roy Woodbury.

1966. Rediscovery of Daphnopsis helleriana. J. Arnold Arbor. 47: 262-265.
(18) Rock, Joseph F.

1913. The indigenous trees of the Hawailan 1slands. 518 p., illus. Published under patronage, Honolulu.

(19) Rock, Joseph F.

1974. The indigenous trees of the Hawaiian 1slands. New ed. 548 p., illus. Pacific Tropical Botanical Garden, Lawai, Kauai, Hawaii. Charles E. Tuttle Co., Rutland, Vt., and Tokyo, Japan. (Reprint of 1913 ed. with updated nomenclature by Derral Herbst and an introduction by Sherwin Carlquist.)

(20) St. John, Harold.

1973. List and summary of the flowering plants in the Hawaiian Islands. Pacific Tropical Botanical Garden Mem. No. 1, 519 p. Lawai, Kauai, Hawaii.

(21) Smithsonian Institution, Secretary.

1975. Report on endangered and threatened plant species of the United States presented to the Congress of the United States of America by the Secretary, Smithsonian Institution. U.S. 94th Congr. 1st Sess., House Doc. No. 94-51, Ser. No. 94-A, 200 p.

(22) Stone, Benjamin C.

1967. A review of the endemic genera of Hawailan plants. Bot. Rev. 33: 216-257.

(23) U.S. Department of Agriculture, Soil Conservation Service.

1975. Rare and endangered plants of Puerto Rico: a committee report. 85 p., illus. In cooperation with the Department of Natural Resources, Commonwealth of Puerto Rico.

(24) U.S. Department of the Interior, Fish and Wildlife Service.

1975. Threatened or endangered fauna or flora: Review of status of vascular plants and determination of "critical habitat." Fed. Regist. 40(127), part V: 27824-27924. Tuesday, July 1, 1975. Washington, D.C.

(25) U.S. Department of the Interior, Fish and Wildlife Service.

1976. Endangered and threatened wildlife and plants. Proposed endangered status for some 1700 U.S. vascular plant taxa. Fed. Regist. 41(117), part 1V: 24524-24572. Wednesday June 16, 1976.

(26) U.S. Department of the Interior, Fish and Wildlife Service.

1977. Endangered and threatened wildlife and plants. Republication of list of species. Fed. Regist. 42(135), part V: 36419-36431. Thursday, July 14, 1977.

(27) Urban, lgnatius.

1903-11. Flora portoricensis. Symbolae Antillanae vol. 4, 771 p., portr.

(28) Weaver, Peter L.

1972. The dwarf forest of Pico del Este and the Luquillo Mountains. Revista Interamericana Review 2: 174-186, illus.

(29) West, H.

1793. Bidrag til Beskrivelse over Ste Croix, med en kort udsigt over St. Thomas, St. Jean, Tortola, Spanish-town og Crabeneiland. 363 p., Copenhagen.

(30) Willis, J. C.

1966. A dictionary of the flowering plants and ferns, ed. 7. Revised by H. K. Airy Shaw. 1,214 p. Cambridge University Press, New York.

(31) Woodbury, Roy O., and Elbert L. Little, Jr.

1976. Flora of Buck Island Reef National Monument (U.S. Virgin Islands). USDA For. Serv. Res. Pap. 1TF-19, 27 p., illus. Institute of Tropical Forestry, Rio Piedras, Puerto Rico.

(32) Woodbury, Roy O., Luis F. Martorell, and Josẻ C. García Tudurí 1971. The flora of Desecheo Island, Puerto Rico. Univ. P. R. J. Agric. 55: 478-505, illus. 
Acacia anegadensis, 9, 13, 16 Acrocomia media, 8, 13 Aegiphila martinicensis, 12 Aiphanes acanthophylla, 8 Allophylus racemosus, 12 Alsophila bryophila, 9, 15 Amyris balsamifera, 12 Andrachne cuneifolia, 4 Aniba bracteata, 11 Antirhea obtusifolia, 9 Antirhea portoricensis, 8 Antirhea sintenisii, 8 Ardisia glauciflora, 8 Ardisia luquillensis, 8

Banara portoricensis, 8 Banara vanderbiltii, 5 Beilschmiedia pendula, 11 Brunfelsia densifolia, 8 Brunfelsia lactea, 8 Brunfelsia portoricensis, 7 Bumelia krugii, 8 Bunchosia glandulifera, 11 Buxus laevigatus, 10 Buxus vahlii, 5, 13

Byrsonima wadsworthii, 9, 15

Caesalpinia monensis, 4, 6 Callicarpa ampla, 7

Calycogonium squamulosum, 9 Calyptranthes kiaerskovii, 5, 13 Calyptranthes krugii, 9 Calyptranthes luquillensis, 7, 15 Calyptranthes portoricensis, 8 Calyptranthes thomasiana, 6, 13 Calyptranthes zuzygium, 11 Calyptronoma rivalis, 6 Cedrela odorata, 11

Cereus quadricostatus, 4, 6

Chione seminervis, 11

Chione venosa, 11

Chrysophyllum bicolor, 12

Chrysophyllum pauciflorum, 10, 14 Cleyera albopunctata, 12

Clidemia umbrosa, 11

Coccoloba pyrifolia, 9

Coccoloba rugosa, 8

Coccoloba sintenisii, 9

Coccoloba teruifolia, 11

Coccothrinax alta, 9, 13

Conostegia hotteana, 11

Cordia borinquensis, 9

Cordia rickseckeri, 9, 13

Cornutia obovata, 7

Cornutia pyramidata, 12

Crescentia portoricensis, 5

Croton fishlockii, 13

Croton poecilanthus, 9

Croton rigidus, 9, 13

Cyathea wilsonii, 10

Cybianthopsis sintenisii, 8, 16

Cynometra portoricensis, 11

Daphnopsis hellerana, 6 Daphnopsis philippiana, 10 Dendropanax laurifolius, 8 Didymopanax gleasonii, 7
Diospyros revoluta, 10

Diospyros sintenisii, 8

Dipholis bellonis, 8

Drypetes ilicifolia 10

Enalagma latifolia, 10

Erythrina eggersii, 8, 13

Erythroxylum rufum, 10

Erythroxylum urbanii, 10

Eugenia boqueronensis, 5, 8

Eugenia borinquensis, 9

Eugenia (?) corozalensis, 5

Eugenia eggersii, 9

Eugenia glabrata, 11

Eugenia haematocarpa, 7, 15

Eugenia procera, 11

Eugenia serrasuela, 5, 8

Eugenia sessiliflora, 9, 13

Eugenia stahlii, 9

Eugenia stewardsonii, 8

Eugenia xerophytica, 9

Eupatorium portoricense, 9

Exostema ellipticum, 12

Exostema sanctae-luciae, 12

Ficus stahlii, 9

Fishlockia, 16

Forestiera eggersiana, 11

Forestiera rhamnifolia, 11

Gaussia attenuata, 8

Gesneria pedunculosa, 9

Goetzea elegans, 6, 16

Grammadenia sintenisii, 8, 16

Guaiacum officinale, 12

Guaiacum sanctum, 12

Guapira discolor, 11

Guettarda valenzuelana, 12

Henriettea membranifolia, 8

Henriettea triflora, 11

Hernandia sonora, 11

Heterotrichurn cymosum, 9

Hibiscus clypeatus, 4, 11

Hirtella rugosa, 9

Hyeronima clusioides, 8

Hyperbaena laurifolia, 11

Illex cassine, 10

Ilex cookii, 5

Ilex guianensis, 10

Ilex sintenisii, 8

Ilex urbaniana, 7, 13

Jacquinia revoluta, 12

Juglans jamaicensis, 5, 11

Laetia procera, 10

Laplacea portoricensis, 7

Leptocereus quadricostatus, 4, 6

Licaria brittoniana, 9, 15

Licaria triandra, 11

Linociera axilliflora, 11

Linociera holdridgii, 8, 15

Linociera ligustrina, 11

Lunania buchii, 10

Lyonia rubiginosa, 8, 13
Machaonia portoricensis, 9

Magnolia portoricensis, 9

Magnolia splendens, 9

Malpighia fucata, 4, 11

Malpighia infestissima, 9, 13

Malpighia linearis, 11

Malpighia pallens, 5, 13

Manilkara jaimiqui, 12

Manilkara pleeana, 8,14

Mappia racenısa, 11

Marlierea sintenisii, 7

Maytenus cymosa, 6, 13

Maytenus elongata, 6

Maytenus ponceana, 6

Meliosma obtusifolia, 8

Menendezia, 16

Miconia affinis, 11

Miconia foveolata, 8

Miconia ottoschulzil, 11

Miconia pachyphylla, 9

Miconia punctata, 11

Miconia pycnoneura, 8

Miconia sintenisii, 9

Miconia thomasiana, 9, 13

Micropholis garciniifolia, 10

Montezuma speciosissima, 9, 16

Mouriri domingensis, 11

Myrcia (?) paganil, 7

Myrica cerifera, 11

Myrica holdridgeana, 8, 15

Nectandra sintenisii, 9

Neea buxifolia, 9, 13

Nephelea portoricensis, 9

Ocotea foeniculacea, 11

Ocotea moschata, 9

Ocotea portoricensis, 8

Opuntia moniliformis, 10

Ossea krugiana, 8

Ottoschulzia rhodoxylon, 5, 11

Ouratea ilicifolia, 11

Ouratea littoralis, 9, 13

Ouratea striata, 11

Oxandra lanceolata, 10

Palicourea barbinervia, 12

Persea krugii, 11

Persea urbaniana, 11

Phialanthus grandifolius, 8, 15

Phialanthus myrtilloides, 12

Phoebe montana, 11

Phyllanthus cuneifolius, 4, 10

Picrasma antillana, 12

Picrasma excelsa, 12

Pictetia aculeata, 13

Piper blattarum, 9

Piper tuberculatum, 11

Piptadenia peregrina, 11

Pleodendron macranthum, 6, 16

Polygala cowellii, 7

Pouteria dictyoneura, 12

Pouteria hotteana, 12

Prockia crucis, 10

Prunus occidentalis, 11

Pseudolmedia spuria, 11

Pseudophoenix sargentii, 5, 11

Psidium amplexicaule, 8,13
Psidium sintenisii, 7

Psychotria maleolens, 9

Psychotria maricaensis, 9

Psychotria nutans, 12

Ravenia urbanii, 7

Reynosia guama, 8, 13

Reynosia krugii, 8

Rhamnus sphaerosperma, 11

Rheedia portoricensis, 9

Rochefortia acanthophora, 10

Rochefortia cuneata, 4, 10

Rollinia mucosa, 10

Rondeletia inermis, 9

Rondeletia pilosa, 12

Rondeletia portoricensis, 9

Roystonea borinquena, 9, 13

Sabal causiarum, 9

Sabinea florida, 13, 16

Sapium caribaeum, 5, 10

Sapium jantaicense, 10

Sapium laurocerasus, 9

Schoepfia arenaria, 6

Schoepfia schreberi, 11

Sida eggersii, 5, 13

Simarouba tulae, 10

Sloanea amygdalina, 10

Solanum antillarurn, 12

Solanum drymophilum, 7

Solanum polygarmum, 12

Stahlia monosperma, 6, 16

Styrax portoricensis, 7

Symplocos lanata, 8

Symplocos micrantha, 8

Tabebuia haemantha, 9

Tabebuia rigida, 9

Tabebuia schumanniana, 9

Ternstroemia heptasepala, 8

Ternstroemia luquillensis, 7

Ternstroemia peduncularis, 12

Ternstroemia stahlii, 10

Ternstroemia subsessilis, 7

Tetrazygia angustifolia, 11

Tetrazygia biflora, 9

Tetrazygia stahlii, 8

Tetrazygia urbanii, 9

Thouinia portoricensis, 10

Thouinia striata, 10

Tournefortia filiflora, 10

Trichilia triacantha, 5

Urera caracasana, 5, 12

Urera chlorocarpa, 5, 8

Wallenia pendula, 9

Weinmannia pinnata, 10

Xylosma pachyphyllum, 8

Xylosma schaeferioides, 10

Xylosma schwaneckeanum, 8

Zanthoxylum bifoliolatum, 12

Zanthoxylum flavum, 12

Zanthoxylum spinifex, 12

Zanthoxylum thomasianum, 6, 14

Ziziphus taylorii, 11 

